\title{
Development and Sexuality of some Species of Olpidiopsis, (Cornu) Fischer. ${ }^{1}$
}

\author{
BY \\ J. T. BARRETT, Ph.D. \\ Associate in Botany, University of Illinois.
}

With Plates XXIII-XXVI.

\section{INTRODUCTION.}

$7 \mathrm{O}$ students of the lower Fungi, there is an especial interest attached to 1 the genus Olpidiopsis, because it is one of the few genera of the Chytridiales that possess a supposed sexual stage. There is also an interesting relation, historically, between the genus and other closely related forms, which emphasizes the danger of hasty conclusions made on imperfect and insufficient observations.

The genus Olpidiopsis was founded by Cornu (6), and although he did not diagnose the genus, it seems strongly probable that the main distinctive character was the presence in the life-history of its members of a resting spore to which was attached an empty smaller cell, called by him the 'cellule adjacente'. This term was, of course, indefinite, and although Cornu believed there existed a sexual relation between the two cells, he had no definite evidence.

Since the first recorded observation of a parasitic fungus on a member of the Saprolegniaceae by Nägeli (18), the same or closely related species have occasionally been described by various observers. In certain cases, the resting spores, which are known to be so necessary for the correct determination of the species, were not observed, hence we have no assurance what the forms were. However, the literature concerning these forms previous and subsequent to the founding of the genus Olpidiopsis is so related in one way or another, that it seems advisable to give a brief review of it here.

As stated above, the first reference to one of these organisms parasitic on the Saprolegniaceae was made by Nägeli in 1846 . He observed in the swollen hyphae of what he called Achlya prolifera, now supposed to have been Saprolegnia ferax, elongated oval structures which eventually discharged their contents, as small motile bodies, to the exterior through

${ }^{1}$ Contribution from Department of Botany, Cornell University, I 42 .

[Annals of Botany, Vol. XXVI. No. CI. January, 1912.] 
a slender tube which perforated the wall of the enclosing hypha. These oval cell-like structures were considered by him as asexual propagative bodies of the Achlya. Cienkowski (5), who carefully illustrated and described the development of a similar organism in the swollen hyphae of Achlya prolifera, considered the oval bodies as a third form of sporangia of the host. He discovered and figured for the first time what he called 'Stachelkugeln', spiny spheres or resting spores. He did not observe their germination.

About the same time Alexander Braun (2) reported, after a long search, that he had succeeded in finding, in a few hyphae of a characteristic form of Saprolegnia on a sick but still living Limneus minutus, the oval bodies described by Nägeli. Some of these were empty, while others were still filled with dark granular protoplasm. He did not observe the discharge of the contents of any of these bodies, but from his own observations and from those previously made by Nägeli, he assumed that the structures concerned were not propagative organs, but parasites of the host. Braun placed the species in his new genus Chytridium with the name $C$. Saprolegniae, and considered the cell-like structures as zoosporangia and the motile bodies as zoospores.

Pringsheim (20), in his work on the sexual organs of the Saprolegniaceae, figures and describes the same or a similar organism. He, however, opposed the view of Braun in that he was inclined to interpret the oval or elliptical bodies found in the hyphae of Saprolegnia ferax, whose oogonia are unaccompanied by male organs, as antheridia, and the zoospores as motile spermatozoids. He also found accompanying the smooth sporangia the 'Stachelkugeln' of Cienkowski. Concerning these he says in part (p. 225): 'Diese Kugeln mit stacheliger Hülle treten entweder isoliert auf oder untermischt mit jenen anderen Körpern, welche eine glatte Hülle besitzen. Man könnte nun geneigt sein, diese Stachelkugeln als die zu den Körpern mit glatter Hülle gehörigen weiblichen Pflanzen zu betrachten, \&c.' In his Fig. I $5 a$, Pl. XXIV, he illustrates a spiny resting spore with what appears to be an attached empty companion cell. He did not observe the germination of the resting spores.

Not until the appearance of Cornu's 'Monographie des Saprolégiées' was the question concerning the nature of these organisms again seriously considered. In the meantime it rested as left by Pringsheim for an interval of some twelve years. Cornu supported the view of A. Braun in considering the bodies in question as parasitic organisms. His careful observations did not include all stages of the life-history of the organisms, nor did he definitely determine experimentally their parasitic nature. He described five species parasitic on members of the Saprolegniaceae, three on species of Achlya, one on Saprolegnia, and one on Aphanomyces. These he included among the Chytridiaceae and in his newly established genus Olpidiopsis. 
Cornu discovered in three of the species an apparently new and interesting type of resting spore, the large spiny cell being accompanied by a smaller smooth, or slightly echinulate, one which he designated as the 'cellule adjacente', as previously mentioned. In the diagnosis of $O$. Saprolegniae, (A. Br.) Cornu, he specifically states that the presence of an adjacent cell is a distinguishing character of that species. He comments upon the fact that, inasmuch as resting spores were not seen by A. Braun, it is impossible to determine the species described by him, but wishing to preserve Braun's specific name, Cornu used it for his species found on Saprolegnia.

Cornu attributed to this new type of resting spore a sexual character. $\mathrm{He}$ considered the large cell an oogonium, and the small one an antheridium.

Reinsch (21), some years later, observed a species of Olpidiopsis in the ends of swollen hyphae of a species of Saprolegnia. He described three types of cells occurring in the same filament. He observed the spiny resting spores with which were associated smaller spherical cells that eventually discharged their contents into the larger. Changes in the protoplasm of the cells were noted, and the actual transfer of the male protoplasm was observed. He states that Pringsheim's assumption as to the sexual nature of the spores is correct, but makes no reference to Cornu's work, which, apparently, he had not seen.

In 1883 Zopf (26) described an interesting species of Olpidiopsis parasitic in Spirogyra, which he named O. Schenkiana. This species is of particular interest in that it shares the peculiarity with one other species of the genus of possessing uniciliate zoospores.

It was observed that the sexual plant arose as a single mass of protoplasm which later put out an evagination to form the companion cell. At the time of fertilization no pore between the two was detected, and Zopf suggested that a diffusion of the male protoplasm through the wall itself took place. At any rate, the antheridium was completely emptied. Zopf had no doubt of the sexual nature of this spore.

The following year, Fisch (10) published an account of a new form, for which he erected the genus Pleocystidium and named it $P$. parasiticum. The species resembles very much $O$. Schenkiana, and was likewise found parasitic on Spirogyra. One important difference exists in the manner in which the sexual spores are produced. In $P$. parasiticum they arise, according to Fisch, from two or more closely associated masses of protoplasm representing separate individuals. One of these becomes what he terms the central cell, and the others the companion cells, or antheridia. Fisch was not certain whether the cellulose membrane eventually formed about the spheres was developed around each individual separately or around all as a whole. He was inclined to the latter view. The actual passage of the protoplasm from the antheridium into the oogonium was observed.

The investigations of A. Fischer (11) contain a very careful description 
of his studies on the development of what he supposed to be Olpidiopsis Saprolegniae, (A. Br.) Cornu. Unable, after much searching, to find an adjacent cell associated with the resting spores, he concluded that so far as $O$. Saprolegniae was concerned it was not present, and he strongly suspected that it was absent in Cornu's other species. Believing that Cornu was mistaken concerning this point and the diagnosis of his genus was incorrect, Fischer (12), in a later work, rejected the adjacent cell character and made the genus Olpidiopsis to include only those forms with resting spores which are not formed as the result of a sexual act. He accepts three of Cornu's species and considers the other two doubtful.

Schröter (22), in the 'Kryptogamenflora von Schlesien', accepted the change made by Fischer, and established the new genus Diplophysa for these parasites possessing an adjacent cell.

In 1892 , in Rabenhorst's ' Kryptogamenflora', A. Fischer (13) gives an explanation of the cause of the confusion which his former work created. In the meantime he discovered a species on Saprolegnia which possessed a resting spore with an adjacent cell. This fact convinced him of the correctness of Cornu's observations, and he therefore restored the genus Olpidiopsis for the form with the adjacent cell. ${ }^{1}$

Inasmuch as the life-history of these organisms, especially the sup. posed sexual stage, is still imperfectly known, through the suggestion of Professor G. F. Atkinson, to whom I am very grateful for his continued advice and kindly criticisms, I am led to take up a study of a few of these forms.

\section{Study of Living Material.}

\section{A. Methods and Material.}

The results of observations presented in this paper are based upon studies made on three species of the genus Olpidiopsis, Cornu (emend. A. Fischer), collected in the vicinity of Ithaca. Two are parasitic on Saprolegnia, the third on Aphanomyces. One of the former, found on $S$. ferax, agrees in every way with the species described and illustrated by A. Fischer in Rabenhorst's 'Kryptogamenflora' as O. Saprolegniae, Cornu, but which, for reasons to be stated later, I believe is not Cornu's species, but a new one for which I propose the name $O$. vexans. The other two species, one found on an undetermined Saprolegnia, and the other on Aphanomyces laevis, are strikingly similar in morphological characters, but because of their biological difference they are believed to

1. c. p. 34. I. Pseudolpidium Saprolegniae mihi. Synon.: Olpidiopsis Saprolegniae, A. Fischer, Schröter. Olpidiopsis Saprolegniae, Cornu pro parte. 2. Olpidiopsis Saprolegniae, (Cornu) mihi. Synon.: Olpidiopsis Saprolegniae, Cornu pro parte. Diplophysa Saprolegniae, Schröter. Pleocystidium, Fisch. 
be distinct. The species found on Aphanomyces is considered new and is given the name O. luxurians, while the other occurring on Saprolegnia is believed to be Cornu's species $O$. Saprolegniae.

These organisms appeared in water cultures prepared for the purpose of obtaining terricolons and aquatic Phycomycetes. Water from streams and pools containing Algae, dead twigs, and débris of various kinds, was placed in small glass vessels in fresh water. When soils were used, about one half-inch was placed in the bottom of the vessel and covered with tap-water one-half to one inch above the soil. The vessels used were provided with glass covers, and measured four inches in diameter and two and a half inches in depth. As traps, various vegetable and animal tissues were tried, such as sections of boiled root of Abutilon, suggested by Butler (4), sterilized flies, millipedes, Dipterous larvae, the larvae and pupae of ants, aphids, boiled egg albumen, \&c. Although all of these, with the exception of the Abutilon root and egg albumen, proved to be more or less serviceable, the sterilized flies, aphids, and ant pupae were more extensively used. Ant pupae and larvae served best when cytological studies were made.

Usually in cultures of this nature the most frequent forms secured are species of Saprolegnia and Achlya. In my cultures, however, Aphanomyces laevis proved to be more common than Achlya species, and was very commonly associated with some species of Saprolegnia. When any Chytridiaceous parasites were present, particularly on Saprolegnia, they could be seen with the naked eye within a few days after the culture had been started. Their presence is detected by the bright whitish specks seen among the radiating hyphae of the host (P1. XXVI, Fig. 75). These specks are the swollen hyphae with the enclosed developing parasite.

When the parasite was once located by means of small scissors, the filaments containing it were cut off under a dissecting lens, washed in sterile water, and transferred to dishes containing pure cultures of the host. By this method reasonably pure cultures were maintained, and infection experiments with the host in various stages of development were carried on.

\section{B. Zoospores.}

The zoospores of the three species agree in all important features. They are oval to broadly elliptical, sometimes slightly reniform or anteriorly truncate. In motion they are usually slightly pointed at the anterior end, to one side of which are attached two cilia, rather close together and of approximately the same length. At the point of attachment of the cilia there is a prominent refractive spot frequently referred to as the hilum. With the aid of the high-power objectives, the protoplasm is seen to be slightly granular and not homogeneous as has been described for other 
species. This condition is more clearly brought out in zoospores killed with osmic acid.

There seems to be considerable variation among the species of this and other related genera in the position and number of the cilia on the zoospores. Cornu (6) observed in all species studied by him but one cilium. A. Fischer (12) found in the case of Olpidiopsis (Pseudolpidium), Rozella, and Woronina that the zoospores possessed two cilia, one placed in front and extending to the fore, the other attached laterally and extending to the rear. This same relation of the cilia was later (13) observed by him for the zoospores of his $O$. Saprolegniae, and was considered to be the normal condition for the genus.

Butler (4) records some interesting observations in reference to this point. He found the arrangement of the cilia as described by Fischer to exist in Olpidiopsis minor, A. Fischer; Pseudolpidium (? Olpidiopsis) Saprolegniae, (A. Br.) A. Fischer; P. gracile, Butler; and Pleolpidium inflatum, Butler. It is interesting to note that in the last-named species, he observed what appeared to be a variation in the position of the cilia. This he attributed to the varying position of the zoospore in swimming. In Pseudolpidium Aphanomyces, (Cornu) A. Fischer, and in Pleolpidium Pythii, Butler, the cilia are attached laterally and at the same point.

It is difficult, in many cases, to observe the attachment of the cilia on the living zoospore. However, this can be done without difficulty with the proper apparatus. Zoospores were allowed to escape from the sporangium into a small hanging drop of water in a Van Tieghem cell, and there observed with a $2 \mathrm{~mm}$. Zeiss apo. obj. by the aid of strong artificial light. As the zoospores come to rest the attachment of the cilia was clearly seen to be at the same point. As has been frequently observed in other species, one cilium of the zoospore in motion trails behind. My observations revealed that this rear cilium crosses at an angle the upper end of the zoospore, and leaving it usually at the side gives it the appearance of being attached at that point. It was not until a number of observations were made that this peculiar condition was detected. When once seen it was easily verified for all the species of Olpidiopsis studied.

The same condition was found on careful examination in stained preparations of zoospores. In cases where the stain was not too deep, the rear cilium could be followed crossing the upper end of the zoospore to its point of attachment near that of the other. Occasionally both cilia extend out free from the body of the zoospore and leave no doubt whatever as to their relative position. In cases which present the appearance of a lateral attachment for one of the cilia, this cilium appears to be shorter than the other, but is actually about the same length (see Pl. XXIII, Figs. I, 2, and I5). A more careful examination of the zoospores of other species 
of these closely related genera may reveal that the above-described relation of the cilia is common, if not the general rule.

As has been described for other species (Butler, 4) there occurs in the life of the zoospores two distinct motile periods. After their escape from the sporangium they swim about actively for a few minutes, two to five, in the vicinity, and then gradually come to rest upon the slide or cover-glass, as the case may be. There is now seen a waving rhythmic movement of the cilia, accompanied by a gentle rocking of the zoospore. These movements become slower and slower, the cilia gradually shorten, and the body of the spore assumes a spherical form. Finally, at the end of seven to ten minutes the zoospore has become quiet, and the cilia, when visible at all, appear as short thickened knobs or projections about the length of the radius of the spore.

The period of rest may last only a few or as many as fifteen or twenty minutes, during which time one, sometimes two, vacuoles are seen to appear and pulsate regularly-in one observed case, at intervals of six to eight seconds-until the second period of motion begins. The reverse condition now takes place. The short cilia begin to move and lengthen, the body of the zoospore resumes the rocking motion, and in a few minutes darts away. There is no change in the position of the cilia, and the fact that, in many cases at least, they do not lose their identity during the resting period makes such an assumption seem improbable. Butler (4) failed to observe cilia on zoospores of Pseudolpidium Aphanomyces during the first period of motion when this was followed by a second. "The fact that such were seen attached laterally on zoospores killed in the sporangium at the time of discharge led him to state (p. I33): 'From this it would appear probable that there is no alteration in the position of the cilia during the two periods of motion, but it is possible that cases occur in which the first period is suppressed, and the sporangium figured may have been such a case.' He further states : 'As in P. Saprolegniae, the occurrence of two periods of motion is not, I think, a constant phenomenon.'

Butler suggests that such a condition may be compared to diplanetism in the Saprolegniaceae and Pythium. Inasmuch as diplanetism seems to prepare the zoospore for a more or less continued period of activity, and that in the cases just described the second period may persist for some time, it seems that, so far as it concerns the Saprolegniaceae, such a comparison is, at least, worthy of comparison.

\section{Infection of the Host.}

Inasmuch as the observations of the writer on the penetration of the host by the zoospores of the parasites differ immaterially from similar studies made by previous investigators, it seems unnecessary to give more than the most important facts as they apply to the species under considera- 
tion. No complete observations relative to this point have been recorded, so far as I am aware, for any Olpidiopsis species parasitic on the Saprolegniaceae.

Cornu (6) briefly describes this phenomenon for certain species studied by him, while A. Fischer (12), for Olpidiopsis (Pseudolpidium), Woronina, and Rozella, records his very careful observations as to both penetration and subsequent development of the parasite.

The zoospores, after a swimming period, the length of which seems to depend considerably on the age and condition of the culture in which it occurs, finally settle down on some favourable part of the host and either produce infection or die. There is at first a slight amoeboid movement, followed by a rounding up of the zoospore body and the formation of a wall (Fig. 3). After resting in this condition for fifteen minutes to one hour, the encysted spore produces from the side in contact with the host a short cylindrical tube which penetrates the wall of the hypha. During this process the zoospores become pushed slightly away from the filament. The penetration tube varies somewhat in length in the different species, being shortest in $O$. luxurians, and longest in $O$. vexans (Figs. 4, 8, and 9). After the formation of the tube, the appearance of a small vacuole in the spore body indicates that the passage of its contents into the host has begun. As observed by A: Fischer (12) and Butler (4) this tube is so small that it is impossible to observe the passage of the protoplasm through it. Occasionally it could be seen extending into the cell cavity beyond the limits of the wall (Fig. 9).

By far the majority of zoospores in all three species fail to infect the host. A greater percentage succeed in $O$. luxurians than in the species on Saprolegnia, due, no doubt, to the fact that infection in this species is not so nearly confined to the young hyphae. Those zoospores which fail to enter the host die sooner or later, either by a direct disintegration of the protoplasm, or after germination. In the presence of the host, and usually near or in contact with the hyphae, zoospores frequently put out long slender germ tubes. These have been observed in large numbers on old empty sporangia of Aphanomyces and on the old threads of Saprolegnia. The germ tubes sometimes entirely surround the hyphae; in other cases they may extend some distance parallel to them (Figs. 5, 6). As has been observed by A. Fischer, the life of the zoospore is much longer in the presence of the host than in pure water.

The germinated zoospores of Aphanomyces are frequently infected by $O$. luxurians (Fig. IO). As many as four developing sporangia of the parasite have been found in a very short germ tube. In no case was an infection of gemmae or reproductive organs of Saprolegnia observed.

Just how far, if at all, chemotropic stimuli set up by the host influence the behaviour of the parasite zoospores is impossible to state. The writer 
has carried on no controllable experiments in reference to this point, but is convinced from careful observations that there is some varying attractive force exerted by the host hyphae on the zoospores of the parasite.

De Bary was inclined to the view that by the secretion of some chemical substance the oogonia of Saprolegnia may be capable of inducing the formation of antheridial branches. This assumption is strengthened by the work of Kauffman (16), in which he showed how the development of sexual organs of Saprolegnia, especially antheridia, could, to a certain extent, be controlled by the use of chemicals.

A. Fischer (12) theorizes that different organs of Saprolegnia, such as young hyphae, gemmae, and oogonia, perhaps give off different metabolic substances, and further that such substances vary in different genera. These diffuse into the surrounding water and within a certain radius exert an attractive or repellent force on the zoospores of the parasite.

\section{Development of the Sporangia.}

Growth period. After the penetration of the zoospore into the host, it can frequently be observed for a brief time as a small, more or less refringent mass of the protoplasm (Figs. 4, IO). It exhibits slight changes in shape, and in the course of an hour or so is entirely lost to view. The young parasite is now more or less surrounded by the host protoplasm, at the expense of which it begins to grow rapidly, and at the same time it exerts upon the host a stimulus which causes, frequently in a few hours, an abnormal development of the infected hypha (Figs. 7, II, 76). Usually the parasite undergoes its development at or near the point of entrance. Frequent exceptions to this condition have been observed, however, and are also noted by Fischer for Olpidiopsis (Pseudolpidium).

The change of position is very probably passive and due to currents of host protoplasm. In cases where a number of sporangia occur in the same intercalary swelling there seems to be no other explanation than that some of the young parasites migrated to that point. Growth of the infected hyphae beyond the position of the parasite usually ceases soon after its infection, especially when such takes place near the end.

In the early stages of development the parasite contains few granules scattered through the homogeneous ground substance, most of them lying about the periphery (Fig. I2). There soon appear a number of larger granules which grow rapidly and present the appearance of being of a fatty or oily nature (Figs. I2, I3, I7). They frequently exhibit a vacuolate character, and show marked changes in form (Figs. I3, 23). Similar granules have been observed by Zopf in $O$. Schenkiana and by Fischer for both species of Olpidiop:is (Pseudolpidium) studied by him.

The parasite now becomes surrounded by a hyaline wall. The proto- 
plasm has become more dense and contains many small granules along with the increased number of oil bodies (Figs. I7, 78). At this time there is a marked radiating condition of the host protoplasm which decreases rapidly in extent as the sporangial development proceeds (Figs. I 7, I 8, 79, 80). Vacuoles of rather indefinite outline now appear in the parasite (Figs. I8, 8I), which soon round up into one or several nearly perfect spheres. The protoplasm is now dense and granular. The large oil or fat-like bodies have disappeared. The sporangium is now said to be ripe and may enter directly into the maturation stages or undergo a limited period of rest before zoospore formation takes place (Fig. 82). I have observed sporangia remain in this condition for several weeks without losing their power of zoospore formation (Fig. I9). The only necessary condition, according to my observations, to start up the internal changes which bring about the discharge of zoospores is that fresh water and oxygen be supplied.

Maturation. Concerning the maturation stages of Pseudolpidium Aphanomyces, Butler (4) has given a detailed account. The changes which take place in the ripe sporangium of the Olpidiopsis species concerned, just previous to zoospore production, agree in the main with those described for the above species. I find, however, that the minute details in the behaviour of the protoplasm vary somewhat with the different sporangia of the same species.

Soon after the proper conditions are supplied to the ripe resting sporangium, one observes a change in the contour of the prominent spherical vacuoles. Usually the exit tubes begin to develop at this time and the protoplasm has the appearance of already being segmented (Figs. I4, 82). No heapings of the protoplasm such as described by Butler for $P$. Aphanomyces were seen to take place at this time. In a short time the vacuoles suddenly disappear, when the protoplasm presents a rather fine granular, homogeneous, and lighter appearance. It is at this stage, according to Butler, that the first shaping of the spore origins in the sporangium of $P$. Aphanomyces occurs. After a few minutes there may or may not appear a number of smaller spherical vacuoles surrounded by the now denser protoplasm.

After fifteen to thirty minutes the vacuoles disappear and the protoplasm becomes more coarsely granular. The zoospores take on a more definite outline and their movement increases. Suddenly the exit tube opens and their escape takes place.

The number and length of the exit tubes vary with the different species. In $O$. luxurians they usually number one or two, and extend some distance beyond the host wall (Fig. I6). In O. Saprolegniae the number of exit tubes is small, one to three, and they are comparatively short. In $O$. vexans they are usually more numerous, often numbering as many as six. Fig. 20 shows a sporangium of $O$. vexans which rested after 
a number of exit tubes had been produced. Several of the tubes show a peculiar coiled condition of the end, while one is branched. This latter condition, which seems rare, was also observed once by Fischer in another species. Other sporangia in a similar stage, when given the proper conditions, failed to discharge zoospores.

The exit tube secretes an enzyme which enables it to penetrate the wall of the host. In many cases, at least, mechanical pressure seems to play an important part. I have several times observed that the host wall was stretched out over the end of the protruding tube even when apparently some little distance through it. Very commonly, as has been previously observed, there is an enlargement of the tube just inside the hyphal wall. The escape of the zoospores takes place by the gelatinization and dissolution of the end of the exit tube.

\section{E. Development of Sexual Spores.}

The frequency of occurrence of the sexual spores of the organisms under consideration varies with the species and the condition of the cultures under which it develops. It has been assumed, in the case of resting spores belonging to species of a closely related genus, that they were formed only after a somewhat prolonged production of the zoosporangia, and then for the purpose of tiding the parasite over unfavourable conditions such as winter. They have been rarely found in the species of Olpidiopsis infecting members of the Saprolegniaceae, which fact, no doubt, partially accounts for our incomplete knowledge concerning their development.

The first of these so-called resting spores found by the writer appeared in a culture of $O$. vexans on Saprolegnia ferax growing on ant larvae. Several cultures had previously been made on sterile flies with the result that only smooth sporangia developed, and it was, therefore, impossible to classify the organism. Three days after starting the culture above mentioned, sexual spores were numerous in all stages of development. New cultures were immediately started with a view to securing material for cytological studies. After making several series of cultures, I was somewhat surprised that the desired spores failed to appear. Almost a month of culture experiments finally revealed the requisite condition. Instead of starting new cultures in separate dishes, as I had previously been doing, I kept the old ones, to which at certain periods I added a new supply of ant pupae. These were disturbed as little as possible, and the water remained unchanged. There were always a sufficient number of zoospores of both host and parasite present to start a ready infection of the new substrata.

By this method the otherwise rapid and vigorous growth of the Saprolegnia was somewhat retarded, and a large number of sexual spores of the parasite developed. It was detected that some contamination by Bacteria, protozoa, \&c., seemed to be an advantage, but when carried too 
far would inevitably prevent the desired results. Not all cultures with this species gave results, and the successful ones needed to be carefully watched in order that their productiveness be maintained. After the sexual spores had attained the desired stage of development most of the larvae were transferred to other vessels in order that new ones could be added. It was necessary, at times, to deviate in one way or another from the regular method described, in order to overcome one or more difficulties.

The sexual spores of $O$. Saprolegniae were as difficult to obtain in quantity as those of $O$. vexans. Those of $O$. luxurians were secured in by far the greatest numbers and with the least difficulty. The host, Aphanomyces laevis, was grown on green aphids, a supply of which was kept sterile in test-tubes. The value of the aphids as culture media was not discovered until most of the cultures of the other species were brought to a close, but the few trials made showed that the aphids were equally serviceable for them. They furnish a very limited amount of nourishment, in that one can find them of all sizes, which fact seems to bear a direct and favourable influence on sexual spore production of the parasite. Correlated with this factor of a small amount of nourishment is the limited amount of water, which should remain unchanged. One disadvantage in the use of small bits of substrata is the reduced size of the sexual spores of the parasite that results. Another advantage obtains in the use of this method. Having the zoospores of both host and parasite in the culture provides for the immediate infection of the host hyphae as they emerge from the substrata. This enables the parasite to get a good start before the hyphae reach any length, and prevents the formation of a tangled mass of hyphae, so objectionable in the preparation of the material for cytological study. The result is a dense halo of short swollen filaments containing the parasites in all stages of development. In the case of the two species on Saprolegnia it is really necessary that infection take place when the hyphae are young.

So far as my observations with the three species of Olpidiopsis go, there seems to be no foundation for a view that a production of sexual spores need be preceded by a somewhat continuous production of sporangia, or that the two need alternate with each other. On the other hand, if the proper external conditions are provided, such spores are more or less easily obtained.

It should be stated here that the above-described method also provided good material of the sporangia in the resting stage.

The sexual spores develop in the same position as the sporangia, with which they may or may not be associated. Usually, however, one finds one or more sporangia in the same hyphal swelling containing sexual spores. The greater the degree of infection of the host, the greater the variation in the size of both kinds of reproductive bodies. In general, the manner 
of development of the sexual spores of the three species agrees. There are, however, some slight differences, especially between $O$. vexans and the other two whose development resembles each other more closely. For the reason stated the former will be described separately.

The developing sexual cells of $O$. vexans are first detected in the young stage by the darker and more dense appearing condition of the protoplasm of, especially, the larger, or female, cell. It does not require very high magnification to see that closely associated with the female plant are one or more smaller light-coloured protoplasmic bodies. These develop into the antheridia, while the larger become the oogonia. Such an early condition is shown in P1. XXIV, Fig. 26. No walls have formed about the cells at this stage, and the very close association of the individuals might suggest a division of a single individual rather than the partial fusion of two or more. At this stage, were it not for the presence of the female cell, one could not distinguish the male elements from the young sporangia of the same age.

As growth proceeds, the two cells become more and more distinct and soon surround themselves by cellulose walls, which become fused at the point of contact. Usually one can clearly distinguish what appear to be brace-walls joining the two cells, as seen in Fig. 27. The wall of the oogonium shows early the formation of roughenings on the outer surface, which eventually take on a warty appearance, and resemble an encrustation of some kind. The male cell, or antheridium, remains smooth.

Noticeable changes also take place in the protoplasmic contents of both cells. In the young stages of growth these resemble those that take place in the young sporangia. There is at first in the oogonial cell a very much vacuolated, finely granular protoplasm in which a few larger irregular granules are distributed. Most of the protoplasm lies in a thin layer about the periphery, from which irregular strands extend into the interior. At this time the male cell shows a somewhat similar vacuolate condition, but contains more granular protoplasm.

Following this stage, which, owing to rapid growth at this period, lasts but a short time, is a stage in which the number of large granules have greatly increased in both cells, to such an extent as to make difficult the observation of protoplasmic changes within, especially in the oogonium. Soon the contents of the female cell become more or less clumped, while that of the male shows a fine granular condition with frequently one or more vacuoles. The cells are now ready for fertilization.

This takes place by the passage of all the antheridial contents into the oogonium. The beginning of this phenomenon is indicated by the appearance of a large central vacuole or, as is more usual, a shrinkage of the protoplasm from the wall of the antheridium opposite the oogonium. The whole act may require several hours or may be completed in less than one hour. I have frequently observed long strands of protoplasm still clinging 
to the opposite wall of the antheridium after most of the contents had passed over. Very rarely does any protoplasm remain in the male cell after fertilization.

Before the movement of the protoplasm of the antheridium into the oogonium begins, one only rarely detects a communicating pore. In fact, in many cases, it cannot be detected even while the passage of the protoplasm is going on. The pore in the fused wall is small and soon closes by growth of the surrounding wall, apparently after the act of fertilization is completed. Owing to the thick encrustation on the oogonial wall, together with the coarsely granular protoplasm, I have been unable to see the movement of the male protoplasm after it has passed through the communicating pore.

As a result of fertilization the oospore forms about itself a wall in close contact with that of the oogonium. This wall rapidly thickens and serves to protect its contents against unfavourable external conditions (Fig. 2I). The now empty antheridial wall may persist for some time in its normal shape, but eventually becomes more or less collapsed.

When more than one antheridial cell is attached to an oogonium there is no apparent difference in their behaviour other than that their contents may or may not simultaneously pass into the female cell. Although one usually finds that the movement has at least started in all male cells before any one is entirely emptied, exceptions to this have been observed.

In the case of the sexual spores of the other two species, O. Saprolegniae and $O$. luxurians, what is said of one will apply equally well to the other. Those individuals which are to give rise to sexual cells can be detected early in their course of development by the difference in the appearance of their protoplasm from that of the young sporangial cells, and by the close association of the two or more individuals. This early condition is not so easily detected, however, as in the case of 0 . vexans.

The protoplasm of both the male and female individuals is much vacuolated and somewhat coarsely granular. The limits of the cells are less clearly defined than those of $O$. vexans because of the closer resemblance of the protoplasm to that of the host (Figs. 24, 83). Later their individuality and form is much more marked, as their protoplasm becomes more differentiated than that of the host (Figs. 25, 84, 85). The oogonium contains large vacuoles surrounded by more or less granular protoplasm, while that of the antheridium is finely granular and homogeneous. At this stage walls have formed, and there is observed a pronounced clear zone of protoplasm about the oogonium, which exhibits a strong contrast to the dense granular layer of the host on which it abuts. Dangeard (7) calls attention to this zone in the resting spores of Olpidiopsis (Pseudolpidium) Saprolegniae, Cornu, as interfering with his observations of the nuclei.

The host protoplasm beyond this layer forms a complicated system of 
radially arranged strands which communicate with a dense peripheral layer, and along which one can frequently observe a movement of granules towards the parasite. This gradually disappears as growth of the sexual elements proceeds, until at maturity these cells lie in an empty swelling.

The vacuoles of the oogonium now become less apparent and the protoplasm is more or less filled with large and small granules. A similar condition prevails also in the antheridium (Pl. XXIV, Fig. 28). Their development is rapid, as is the disappearance of the host protoplasm which surrounds them.

After fertilization the oospore develops a thick endospore. Fig. 30 shows a mature oospore of $O$. luxurians bearing two empty antheridial cells. The content is differentiated into an outer zone, more or less finely granular, and a central mass of large, more or less regular granules in which is usually one or more large oil globules. The oil globules are not represented in this figure. Occasionally in these species one finds the peculiar condition of one antheridial cell attached to two oogonia, one of which is usually provided with a separate male cell (Pl. XXVI, Fig. 88). Fig. 85 shows a young oogonium with three antheridial cells attached.

The fertilization pore in the sexual spores of these species is, so far as can be determined in the living material, not unlike that described for 0 . vexans. It has frequently been observed, and in some few cases the stream of male protoplasm could be seen passing through it into the female cell. In one interesting case, while observing this act, the weight of the cover-glass, because of evaporation of water under it, suddenly came upon the oogonium as the last of the antheridial contents was passing into it. Immediately a stream of protoplasm was forced through the pore and the male cell was soon refilled.

As yet, no case of germination of the oospores has been observed for any of the species studied. A. Fischer (11) witnessed the germination of the resting spores of Olpidiopsis (Pseudolpidium) and Zopf the same phenomenon for $O$. Schenkiana. In both cases germ tubes were formed through which zoospores escaped.

Reinsch (21) observed, in a species of Olpidiopsis (according to A. Fischer 0. minor), that at the point of fusion of the two sexual cells a slit formed in the wall which permitted the passage of the male protoplasm into the oogonium. This opening, after fertilization, was closed by growth.

In $O$. Schenkiana Zopf (26) saw no communicating pore or opening between the two sexual cells. To him the contents of the antheridium seemed to diffuse through the wall into the oogonium. I have not had the opportunity to observe the condition in that species, but judging from the ease with which such a pore might be overlooked in the species studied, it seems probable that it occurs in O. Schenkiana. 


\section{- 3. Study of Sections.}

\section{A. Methods.}

The material used for sectioning was secured as described under the heading 'Methods and Material'. The substratum bearing the organisms was washed in several changes of water in order to free it as much as possible from all contamination, then dropped into small phials of killing solution. The latter consisted of weak and strong Flemming's solution, medium and strong chrom-acetic acid, and Gilson's fluid. After killing and fixing, the material was washed either in slow running water or by making frequent changes by means of a pipette. Dehydration was secured both by carrying the specimens through the grades of alcohol, and by evaporating down in Io per cent. glycerine. After clearing in cedar oil, the material was embedded in paraffin. Sections were cut $2-5 \mu$ thick and stained on the slide.

The stains used were Flemming's triple stain, with the orange G. dissolved in the clove oil, Heidenhain's iron-alum haematoxylin, and Gram's stain followed by eosin in clove oil. For most purposes material fixed in medium chrom-acetic acid and followed by the triple stain gave the best results. The same stain applied to material fixed with Flemming's solutions served best for the maturation stages of the sporangium, and for staining the nuclei of the host. Iron-alum haematoxylin was of little service, while Gram's stain was excellent for bringing out the nuclei during fertilization stages.

Very little histologically and cytologically has been done on the members of the family Olpidiaceae, and nothing, so far as I have been able to learn, on the genus Olpidiopsis in the sense used in this paper.

Dangeard (7) studied the histology of two species of the genus Pseudolpidium, then called by him Olpidiopsis Saprolegniae, Cornu, and O. Aphanomycis, Cornu. Inasmuch as the two genera are very closely related, it seems proper to give briefly the results of Dangeard's observations on the above species. The material studied by him was stained in toto, which prevented the clearest definition of the nuclei, especially in the resting spores.

According to Dangeard, the sporangia of $O$. Saprolegnia, Cornu, present two principal phases in their development. In the young condition the protoplasm is very much vacuolated, and is composed superficially of broad meshes at whose nodes are located the nuclei. The nuclei are very small and appear as simple masses of chromatin. From a uninucleate to a multinucleate condition the change is rapid, there being present about twenty at the time the sporangium reaches its final size. Later, the nuclei which have increased in number space themselves, and show 
dense, rather large masses of chromatin, which are surrounded by nuclear hyaloplasm.

Successful examination of the histology of the resting spores was impossible. Dangeard observed that the dark zone of colourless protoplasm about the developing spore hindered observation. He states that they are multinucleate.

Concerning the study of the second species, O. Aphanomycis, Cornu, nothing of importance was added. Dangeard observed a spiny resting spore without a companion cell, which would place this species in the genus Pseudolpidium as P. Aphanomycis.

\section{B. Sporangia.}

Fig. 3 I , Pl. XXIV, represents a young parasite soon after its entrance into the host. It is uninucleate, much vacuolated, and not unlike Fig. 35, which is a zoospore from a discharging sporangium. The protoplasm, which is finely granular, exists in the form of a parietal layer. Growth of the individual has not proceeded far until the single nucleus divides.

Fig. $3^{2}$ shows the binucleate stage. The nuclei are prominent and contain large deeply staining bodies which are presumably nucleoli. As is seen in Fig. 33, the nuclei divide mitotically. Fig. 34 is a section through a slightly older individual, showing three of its four nuclei and the very much vacuolated and granular nature of the protoplasm. It is assumed, from the condition of the protoplasm, that it is about this time in the life of the individual that it becomes lost to view in the host.

Nuclear divisions proceed rapidly, and we soon find the condition shown in Fig. $3^{6}$. It will be observed that the protoplasm lies principally in the peripheral layer, in which are embedded the many still prominent nuclei. There is also observed a tendency for small granules to collect about the outside of the parasite, indicating, perhaps, the beginning of the formation of a wall, as a very little later one finds that a thin wall has developed. The large irregularly shaped fat bodies observed in the living specimens are in most cases not visible in stained sections.

Following the condition shown in Fig. 36 , there is a gradual inward growth of the protoplasm, accompanied by an increase in size of the parasite and a continued rapid nuclear division. A little later the sporangium is almost filled with fine granular protoplasm in which are distributed a few large and numerous small irregularly shaped vacuoles. Fig. 37 represents a section of a small sporangium at that period of development with its nuclei undergoing their last division. The sporangial wall is very distinct and the sporangium has probably reached its maximum size. The large vacuoles have become regular in outline and at the same time the smaller ones show less distinctly. 
Fig. $3^{8}$ illustrates that condition. It shows the appearance of the nuclei after the last division, and around which the individual zoospores are to form. Chromatin masses are arranged about the nuclear membrane in more or less irregular areas. It is in this stage that the sporangium may undergo a period of rest.

I have observed no indication of an amoeboid or otherwise irregular stage of the parasite. A. Fischer (11) describes such a condition as common for 0 . (Psendolpidium) Saprolegniae even after the parasite had reached some size (see P1. X, Fig. 5, $a-d$ ). In the young living specimens it is sometimes very difficult to determine the limits of the host and parasite protoplasms, but in stained sectioned material such a difficulty disappears, for the reason that the protoplasm of the parasite has a different affinity for stain than that of the host. There is no indication whatever of a fusion of two or more parasites to form one, and it seems very evident that each zoospore after entering the host maintains its individuality and gives rise to a single sporangium. In other words, no plasmodium is formed. In abundantly infected material one frequently finds in section a number of very small individuals, sometimes still uninucleate, accompanying the larger ones in swollen hyphae whose protoplasm has been exhausted. In some cases these small parasites have taken on a mature state and may give rise to a small number of zoospores.

Fig. 39 represents a portion of a section of a sporangium in the vacuolate resting condition, and of the same age as that from which Fig. 38 was drawn. The former was killed in weak Flemming's solution, the latter in medium chrom-acetic acid. This section shows very clearly that the uninucleate spore centres are not only definitely formed at this time, but that fragmentation has, at least partially, taken place. The nuclei take a deeper stain than those shown in Fig. 38 , in which lines of segmentation of the protoplasm are not visible. There is no apparent indication of vacuoles in the young spores, which indicates, it seems, that during the resting period of the sporangium the water of imbibition of the spore centres is at a low ebb.

From this and many other similar sections I think it is evident that the spore centres are formed before the resting period of the sporangium ensues. The changes which take place subsequently to the resting period, and which have been supposed to give rise to the fashioning of the spore centres, are merely the phenomena accompanying the final stages in the development of the zoospores.

So far as could be determined, fragmentation of the protoplasm is simultaneous throughout the sporangium much as described by Dangeard (7) for the primitive cell of Synchytrium Taraxaci. When exit tubes are present at this stage their protoplasm likewise shows segmentation into spore centres. 
At the time of discharge of the sporangium the vacuoles disappear, while they are very evident in the zoospores themselves. The zoospores reach the exterior then, not, as Harper (15) described for Synchytrium decipiens, in the form of concentrated bits of protoplasm, but as definitely vacuolated structures (Fig. 35). Butler's assumption that an increase in the imbibition water is necessary to the final fashioning of the zoospores seems to be substantiated by my sections.

In sections stained with Gram's stain there are seen in the vacuoles of the sporangia spherical or oval faintly staining bodies the nature of which was not determined (P1. XXIII, Fig. 22). They were not observed after the use of any other stain. They need further study.

\section{Sexual Organs.}

Very early in the development of the individual parasite, which is to become the oogonial cell, there is a noticeable difference in its staining reaction. While the protoplasm of all the parasites destined to give rise to sporangia and antheridia has a strong affinity for gentian violet, that of the oogonial cells shows very early a tendency to give up that stain and hold to the orange $G$. This fact enables one to recognize the young oogonial cell very early.

Most of the material studied in section was that of 0 . vexans because of the larger sexual individuals and their better response to stains. In the youngest oogonial cell of which I could be sure, the nuclei already numbered twenty-five to thirty. Some were distributed more or less irregularly throughout the contents, while the rest were arranged about the periphery embedded in a thin layer of finely granular protoplasm.

Fig. 40, Pl. XXV, represents the earliest stage seen in section in which both male and female cells showed. Enclosing walls have not yet formed and the two gametes are in close contact with each other. The nuclei of both individuals are undergoing mitotic division, and both show a marked vacuolate condition. The male cell possesses, as is the usual condition, proportionately more granular protoplasm. Most of the protoplasm of the oogonium is arranged about the periphery and contains many of the nuclei.

Following this condition there is a rapid increase in the size of the gametes and in the number of nuclei. By the time the cells reach their mature size they are enclosed in cellulose walls. The wall of the antheridium remains smooth, while that of the oogonium soon begins to take on a roughened character.

Fig. 4I shows portions of the two individuals with their walls fused and brace-walls formed. Already gelatinization of the common wall is taking place to form a fertilization pore. This can be detected by the deep stain of the wall at that point. The protoplasm is now more coarsely granular and much vacuolated, especially in the female cell. 
Fig. 42 shows an advanced stage of gelatinization of the wall and its diffusion into the contents of the two cells. The nuclei of the oogonium are in the resting condition, while those of the antheridium are undergoing division. Fat globules are scattered throughout the female protoplasm, which is still sparse and exhibits a rather poor affinity for stain in contrast to that of the antheridium.

The next condition that one observes is the beginning of the passage of the protoplasm of the antheridium into the oogonium. Fig. 43 represents a section of the sexual cells of O.luxurians stained with Gram's stain, which shows this stage. It is interesting to note that the female nuclei located at the nodes of the protoplasmic meshes are very faint. This is due to the fact that, in order to bring out the male nuclei embedded in the dense, deeply staining protoplasm and gelatinized wall substance, it was necessary to decolorize to such an extent that the female nuclei lost their colour. The nuclei in different stages of division have different affinities for stains. In fact, many sections of antheridia fail to show them, while the nuclei of the accompanying oogonia are perfectly clear and distinct.

There seems to be no relation between the beginning of the passage of the protoplasm and the condition of the nuclei. They have been observed in various stages of division in both cells at the time the transfer of the protoplasm was taking place.

After the completion of the act of fertilization some change takes place in the fused protoplasm which alters its susceptibility to stain. The contents have a much greater affinity for safranin than previously and take up very little of the gentian violet. The nuclei now become distributed irregularly throughout the oospore in variously sized groups (Fig. 44), and are much smaller. The number of oil globules increases rapidly, the oogonial wall begins to thicken, and the communicating pore becomes closed. The nuclei appear under the lower powers as mere rings, but when examined with very high powers can be seen to possess peripherally arranged, deeply staining masses of chromatin (Fig. 46). They are much smaller than formerly.

There is no apparent difference in the male and female nuclei, and this fact, coupled with their extremely small size, makes it impossible to definitely follow their subsequent relation to each other. However, there are indications which strongly suggest a fusion of nuclei. Whether this fusion is always in pairs I am at present unable to say, but in the light of our present knowledge concerning compound fertilization this, it seems, would be assumed. Fig. 47 represents a portion of a section of an oospore of further development. The nuclei, although faint, are much larger than in previous stages and fewer in number. They are more regularly distributed throughout the interior, with a tendency to collect about the periphery. The endospore is now well developed.

In Fig. 48 are shown some nuclei from oospores, highly magnified; 
$d-g$, as they appear soon after the two protoplasms have become fused; $b, c$, and $h$, in the fusion stage; $a$, large nuclei from the section represented in Fig. 47 .

Unfortunately, no later stages of the oospores of this species were observed in section. In the other species, however, an interesting arrangement of the contents of the mature oospores takes place. Fig. 46 shows a portion of a section of an almost mature oospore of 0 . luxurians. The content is more or less differentiated into zones which show different staining reactions, especially with the triple stain. The outer zone is made up of fine granular protoplasm in which are embedded a large number of faintly staining nuclei. Inside of this is a zone of less definite outline composed of larger granules which stain rather deeply with gentian violet. The outer zone retains more of the safranin. In or near the centre is a large oil globule which stains with orange $G$.

Fig. 45 shows a section of a mature oospore. The same zonate character of the contents is evident. Fig. 90 is a photomicrograph of the same section. When iron-alum haematoxylin is used on such material the zonate character is less distinct and the nuclei can rarely be seen at all (Fig. 89).

The endospore becomes very much thickened in the mature oospore, while the hyaline spine-bearing exospore remains unchanged. The former stains slightly with orange $G$ and eosin, the latter usually remains hyaline. In sections of $O$. vexans oospores there is only an occasional indication of a roughened or warty condition of the exospore, which would point to the assumption that such markings were due to some encrustation which dissolved in the preparation of the material.

There is no contraction of the oogonial protoplasm to form an oosphere and no apparent changes comparable to those taking place in oogenesis in the higher Oomycetes. After fertilization the oogonium becomes the oospore directly.

\section{Nuclear Division.}

The nuclei of both sporangia and gametes are small, measuring in the resting stage $4-5 \mu$ in diameter. In the early stages of development of the sporangia, and up to the time of fertilization in the sexual spores, they have a rather strong affinity for stains, especially in division stages. The nucleoli and chromatin masses take on a brilliant red colour with safranin, while the spindle fibres stain very faintly with gentian violet. All material fixed in Flemming's solution proved much less satisfactory than that fixed with medium chrom-acetic acid for nuclear divisions.

The resting nucleus (Figs. 49 and 50) possesses a deeply staining, rather prominent nucleolus and a slightly granular nuclear plasm. A rather indistinct network with frequent deeply stained thickenings, which I take to 
be the chromatin material, is present. In cases (Fig. 5I) where the nucleolus is absent, the chromatin masses are more prominent. They apparently become elongated and not infrequently assume the condition seen in Fig. 54. The conditions illustrated in Figs. 52 and 53 are frequent. They resemble somewhat the synaptic knot of higher plants, but I do not believe that to be their nature.

Following the condition seen in Fig. 54, the chromosomes become massed together into a large, deeply staining body from which the tips of the spindle appear to emerge. The poles finally extend to the nuclear membrane, which usually persists to the late metaphase or early anaphase.

Figs. 55 and $5^{6}$ show spindles in the metaphase with large undifferentiated chromatin masses. Figs. 57-62 show indications of individual chromosomes of a rounded or globular form, which, as nearly as I could determine, number six (Fig. 66). In Figs. 57 and 59-6I the chromosomes have evidently divided, while in Figs. 63 and 65 they are passing in mass to their respective poles of the spindle. The nuclear membrane has practically disappeared.

Figs. 67-73 represent succeeding conditions in the anaphase and telophase stages. The conditions represented in Figs. 69-73 are not uncommon, especially in the sexual elements. Similar stages in dividing nuclei have been illustrated for the rusts as well as for a few other Fungi. Fig. 73 represents the still united daughter nuclei with their respective nuclear membranes partially formed. No indication of direct nuclear division was seen.

Very commonly, if not in the majority of cases, the nuclear spindle was more or less bent (Figs. 55-7,60, 61, and 65). In every case of this kind the poles of the spindle were in contact with the ends of the oval or elliptically shaped nuclear membrane. There was no indication of centrosomes or any structure which would suggest nuclear polarity.

\section{Description of Species.}

In 1872 Cornu (5) described a species of Olpidiopsis to which he applied the name $O$. Saprolegniae. He was unable to determine whether or not it was the same form observed by A. Braun, but as he wished to preserve Braun's specific name he used it for his species.

In the description of this species Cornu specifically states that the resting sporangia are provided with a large number of very small spines, and are accompanied by an adjacent cell with a smooth wall. He further states: 'It is solely upon that species that the name $O$. Saprolegniae is to be applied. The form of the sporangia, however variable in the species of that group, is not necessarily spherical. The character of the species is not drawn from that, but from the presence of a smooth adjacent cell, coupled with an oospore provided with a large number of spines, isolated and not formed by ridges.' 
Cornu's illustration (PI. III, Fig. IO) of the oospore of this species certainly clearly shows definite spines on the mature oospore rather than warts or tubercles.

A. Fischer (13), in 1892 , described what he considered as $O$. Saprolegniae as possessing resting spores with the outer wall thickly covered with hemispherical or blunt colourless warts up to $3 \mu$ high. I am unable to reconcile this with Cornu's description. I believe that Fischer was dealing with a distinct and new species for which, as previously stated, I propose the name $O$. vexans.

Olpidiopsis vexans, nov. sp.

Synon. O. Saprolegniae, A. Fischer, I892. Rabenhorst's 'Kryptogamenflora von Deutschland', I, lv, $3^{8}$.

Sporangia, single or multiple, formed in terminal or intercalary swellings of the host hyphae, elliptical, oval, or spherical, very variable in size, up to I $76 \mu$ in diam., with smooth, colourless membrane, colourless contents, and one to several unbranched exit tubes; zoospores elongated, slightly inequilateral, with two cilia attached at or near the anterior end. Oospores dark grey, with one, sometimes two, antheridial cells; oospores surrounded by a thick endospore and a thin warty exospore, spherical to oval, sometimes elliptical, up to II $6 \times 84 \mu$, average $50 \mu$ in diam.; antheridia spherical, less commonly oval, average diam. $20 \mu$, with a smooth, colourless wall. Germination of oospores not observed.

Zoosporangiis solitariis v. numerosis, in cellula matricis terminalibus $\mathrm{v}$. intercalaribus viventibus, ellipsoideis, ovalibus, v. sphaericis, magnitudine variis, 50-I $76 \mu$ diam., hyalinis, membrana tenui, levi ; zoosporis numerosis, elongatis; ciliis duobus, apici v. proximis apici insertis; oosporis, griseis, sphaericis ad ovalia, interdum ellipsoideis, circ. II $6 \times 84 \mu$ (saepissime $50 \mu$ diam.), endosporio crasso, levi, episporio tenui, verrucoso ; cellulis antheridiis hyalinis, sphaericis ad ovalia, membrana tenui, levi cinctis, $20 \mu$ diam.

Hab. in Saprolegnia ferax, Ithaca, N.Y.

Olpidiopsis luxurians, nov. sp.

Sporangia single or multiple, formed in terminal or intercalary swellings of the host hyphae, oval to spherical, very variable in size, with one to three exit tubes extending considerably beyond the wall of the host; zoospores rather small, elongated, with two cilia attached at or near the anterior end. Oospores spherical, with one or two, rarely three, antheridia, with a thick endospore and a thin exospore provided with numerous conical spines up to $2.5 \mu$ in length; oospores $25-50 \mu$ in diam., contain one or more large oil globules ; antheridia spherical, frequently oval to elliptical, I o-2 $5 \mu$ in diam., with a smooth colourless wall. Germination of oospores not observed.

Parasitic in Aphanomyces laevis, de Bary, Ithaca.

Zoosporangiis solitariis $\mathrm{v}$. numerosis, in cellula matricis plerumque intercalaribus viventibus, ovalibus ad sphaerica, magnitudine variis, collo $\mathrm{I}-3$ 
extra cellulam matricis valde prominente ornatis ; zoosporis minutioribus, elongatis ; ciliis duobus, apici v. proximis apici insertis ; oosporis sphaericis, 25-50 $\mu$ diam., endosporio crasso, episporio tenui, spinis numerosis, conicis, basi dilatatis, apice acutissimis; antheridiis sphaericis, saepe ovalibus ad elliptica, IO-25 $\mu$ diam., membrana levi hyalina inclusis.

Hab. in Aphanomyces laevis, de Bary, Ithaca, N.Y.

This species is made not unmindful of the fact that the form resembles rather closely in some respects 0 . minor, A. Fischer, especially as described and illustrated by Petersen $(19$, p. 405). The fact that the spines are much more slender than those illustrated by Cornu (6, Pl. IV, Figs. 3 and 4$)$ and that this form could not be transferred to the hosts on which $O$. minor, Fischer, was found, seems to the writer to warrant the establishment of a new species.

\section{Olpidiopsis Saprolegniae, Cornu.}

Sporangia single or multiple, formed in terminal or intercalary swellings of the host hyphae, elliptical, oval to spherical, very variable in size, up to I $50 \mu$ in diam., with one, less commonly two, exit tubes; zoospores oval to elongated, with two cilia attached at or near the anterior end. Oospores spherical, with one or two, less commonly three, antheridia, with a thick endospore and a thin exospore bearing numerous slender spines up to $10 \mu$ long in large specimens ; oospores very variable in size, up to I07 $\mu$ in diam., provided with oil globules; antheridia spherical to oval, with a smooth colourless wall. Germination of the oospores not observed.

Parasitic in Saprolegnia species. Ithaca.

This species is in some respects similar morphologically to $O$. luxurians. Cross-inoculation experiments with the two species and their hosts revealed that neither could be transferred to the host of the other. This would indicate that they were at least biological, if not morphological, species. The spines of the latter are slightly more slender than those of the former.

The description as given above for $O$. Saprolegniae differs in some minor points from that prepared by Cornu, but on the whole seems too close to it to warrant the formation of a new species.

\section{General Considerations.}

The presence of true sexuality in the Chytridiaceae is, indeed, rare. Urophlyctis and Olpidiopsis have been supposed to possess such a stage, but no cytological evidence has been brought forth. Fisch (10) described the copulation of small motile gametes in Reessia, while Sorokin (22), according to Butler (4), reports a similar phenomenon for Tetrachytrium. A. Fischer (13) accepts neither of these results, but in view of the fact that Griggs (14) has recently reported a similar condition as existing in his new genus Monochytrium, their correctness seems more probable. An interesting 
sexual relation is found in the new genus and species Zygorhizidium Willei described by Loewenthal (17).

The one species, aside from that of Monochytrium, that is well known from a cytological point of view, is Polyphagus Euglenae, Now. Nowakowski described the external phenomenon of the union of the two individuals, but the internal behaviour relating to fertilization has until recent years remained unknown. The cytology of the form was first worked out by Wager (25). According to him the unicellular elements are uninucleate. After the fusion of the two protoplasms there ensues a period of rest, and it is not until the time of germination of the zygote that the sex nuclei fuse.

Dangeard (9) took up the study of the same organism and published a long memoir on it. He confirmed in general the results of Wager. $\mathrm{He}$ believes that copulation can take place with the male element before it has attained its complete development. This would appear to be another proof of his general theory of sexuality. According to this theory, living forms primitively asexual have become sexual on account of their resistance to unfavourable conditions where they live. In particular, the exhaustion of nutritive material brought about a sort of starvation which induced the appearance of sexual attraction.

The similarity of the mode of development and nuclear behaviour of the sexual elements of Olpidiopsis species, together with the relation of internal conditions to the development of the gametes, point strongly to the belief that they are morphologically equivalent to the sporangia. Many of the sporangial characters are retained by the male cells or antheridia up to the time of fertilization, while more marked differential changes in the oogonial forming individuals take place much earlier.

There appears to be no definite or proper time for the transference of the male protoplasm into the oogonium, at least so far as the behaviour of the nuclei is concerned. In other words, fusion of the sex protoplasm may take place before the maturity of one or both cells.

These characters, it seems, point to a primitive condition of the sexual stage. This view would, according to some students, be strengthened by the coenogametic nature of the sex individuals and the multinucleate character of the resulting oospore. This condition, however, is not confined to the lower forms. A similar condition was described by Stevens (24) for Cystopus Bliti in a genus showing what appears to be a sequence of species ranging, so far as numbers of fusion nuclei present in the oospore are concerned, from Cystopus Bliti to Cystopus candidus where only a single nucleus is present. Such a sequence occurring among closely allied species seems to indicate the gradual change from a primitive form to the more usual condition when only one nucleus is present. But when one considers that the sex cells of Polyphagus Euglenae are uninucleate, and the sex cells and resulting oospores of Olpidiopsis and Ancylistes Closterii, Pfit. (Dangeard, 7), are multinucleate, 
the importance of such conditions seems lessened. These facts concerning the nuclei of these forms indicate a relationship between Polyphagus and Ancylistes as close as between Polyphagus and Olpidiopsis, both belonging to the Chytridiales. The former probably represents an early type of the Zygomycetes, while the latter represents a primitive Oomycete. Similar types are found among the Ancylistales, as Ancylistes for the Oomycetes and Zygochytrium for the Zygomycetes, although the cytology of the latter form is not known. Lagenidium also shows a relation to the Zygomycetes, but here again nothing is known about its cytology.

The entire absence of an antheridial tube and the passage of the entire contents of the antheridium into the oogonium suggest, according to Atkinson (1), ' a primitive and generalized condition of sexuality rather than a condition of degeneration from forms in which it is more highly specialized.'

It would be interesting to know the cytology of the closely related genus Pseudolpidium, in which resting spores very similar to those of Olpidiopsis, but without a companion or antheridial cell, are produced. In view of the conditions found by Fisch (10) in Reessia and Griggs (14) in Monochytrium, it seems not altogether impossible that in that genus there may be a similar fusion of elements that has been overlooked.

\section{Summary.}

I. The zoospores of all three species of Olpidiopsis studied possess two cilia of equal length attached at or near the anterior end of the elongated body. They have two motile stages separated by a brief period of rest, which suggests a primitive type of diplanetism.

2. The individuality of the zoospore after entrance into the host is maintained throughout its development, there being no plasmodium formed. Aside from a slight amoeboid movement immediately after entrance, the parasite does not undergo any noticeable changes in form.

3. Segmentation of the sporangial contents has, at least partially, taken place before the entrance of the sporangium into a period of rest, when such occurs, and is apparently simultaneous throughout. The zoospores on escaping contain vacuoles.

4. True sexuality probably exists, and takes place by the fusion of two sexually differentiated individuals and the subsequent passage of the protoplasm of the smaller, male, into the larger, female, cell. This is followed by a supposed fusion of nuclei.

5. Both sexual and asexual reproductive bodies develop rather rapidly from a uninucleate to a multinucleate condition. The oospore is likewise multinucleate.

6. External conditions play a great part in the determination of sex in these organisms. This fact adds evidence to the doctrine that sex in many plants is determinable by external or nutritive conditions. 
7. Nuclear division is mitotic with the spindle intranuclear. The number of chromosomes is approximately six. No centrosomes nor any other indication of nuclear polarity was observed.

8. These forms seem to be primitive sexual organisms of the Oomycete type. The influence of external conditions on the development of the sexual stage, the mode of fertilization, the unequal size of the two gametes, and the apparent morphological equivalence of these gametes with the sporangia, seem to the writer to point to that assumption.

\section{BIBLIOGRAPHY.}

1. Atkinson, G. F.: Some Problems in the Evolution of the Lower Fungi. Annales Mycologici, vii, I909, pp. 44I-72, 20 text-figs.

2. BRAUN, AL。: Ueber Chytridium, eine Gattung einzelner Schmarotzergewächse auf Algen und Infusorien. Monatsbericht Königl. Preuss. Akad. d. Wiss., Berlin, I 855, pp. 378-84.

3. - Ueber Chytridium, eine Gattung einzelner Schmarotzergewächse auf Algen und Infusorien. Abhandl. d. Königl. Preuss. Akad. d. Wiss., Berlin, I856, pp. 2 I-83, pl. I-5.

4. Butler, E. J. : An Account of the Genus Pythium and some Chytridiaceae. Memoir of the Dept. of Agr. in India, Bot Ser., i, 1907 , No. 5, pp. I-160, pl. I-10.

5. Cienkowski : Algologische Studien, I. Bot. Zeitung, xiii, I872, pp. 80I-6, pl. I 2.

6. Cornu, M.: Monographie des Saprolégniées. Ann. des Sci. Natur., Bot., sér. 5, xv, 1872 , pp. I-I98, pl. I-6.

7. Dangeard, P. A.: Recherches histologiques sur les Champignons. Le Botaniste, ii, 1890, pp. $63-146$, pl. $3-7$.

8. - Théorie de la sexualité. Le Botaniste (in Mémoire sur les Chlamydamona. dinées), vi, I 898, pp. 263-90.

9. - Recherches sur la structure de Polyphagus Euglenae, Now. Le Botaniste, vii, 1900, pp. 2 I 3-57, pl. 6, 7 , text-figs. I-3.

10. Fisch, C.: Beiträge zur Kenntniss der Chytridiaceen. Sitzb. der Phys.-Mediz. Gesellsch. zu Erlangen, 1884, pp. I-48, pl. I.

11. Fischer, A.: Ueber die Stachelkugeln in Saprolegniaschlänchen. Bot. Zeitung, xxxviii, J880, pp. 689-96, 705-I I, 72I-6, pl. Iо.

12. 1882, pp. 286-371, pl. I3-15.

13. : Phycomycetes. Rabenhorst's Kryptogamenflora von Deutschland, I, iv, I892.

14. Griggs, R. F. : Monochytrium: a New Genus of the Chytridiales, its Life History and Cytology. Ohio Nat., x, I910, pp. 44-54, pl. 3. 4.

15. Harper, R. A.: Cell-Division in Sporangia and Asci. Ann. Bot., xiii, 1899, pp. 467-525, pl. $24-6$.

16. Kauffman, C. H. : A Contribution to the Physiology of the Saprolegniaceae. Ann. Bot., xxii, I908, pp. 36I-87, pl. 23.

17. Loewenthal, W.: Weitere Untersuchungen an Chytridiaceen. Archiv für Protistenkunde, V, 1905, pp. $22 \mathrm{I}-38, \mathrm{pl} .7,8$.

18. NÄGELI: Zeitschrift für wiss. Bot., i, 1846 , p. 29 , pl. 4 .

19. Petersen, H. E.: Studier over Ferskvands-Phykomyceter. Særtryk af Botanisk Tidsskrift, $\mathrm{xxix}, 1909, \mathrm{pp} \cdot 345^{-440}, 27$ figs.

20. Pringsheim, N.: Nachträge zur Morphologie der Saprolegnieen. Jahrb. für wiss. Bot., ii, 1860, pp. 205-36, pls. 22-5. 
21. Reinsch, P.: Beobachtungen über einige neue Saprolegniaceen. Jahrb. für wiss. Bot., xi, I 878 , pp. 283-3II, pl. I4-I 7 .

22. Schröter : Kryptogamenflora von Schlesien. III, i, I886, p. I95.

23. Sorokin, N.: Matériaux pour la Flore cryptogamique de l'Asie Centrale. Rev. Myc., xi, r889, pp. 69-85, I 36-52, 207, 208, pl. 78, 83, 85-92; xii, I890, pp. 3-I6, 49-6I, pl. 93-I I I.

24. Stevens, F. L. : The Compound Oosphere of Albugo bliti. Bot. Gaz., xxviii, 1899, pp. I49I $76,225-45, \mathrm{pl}$. I I-I 5 .

25. Wager, H.: The Sexuality of the Fungi. Ann. Bot., xiii, I 899, pp. 575-97.

26. Zopf, W. : Zur Kenntniss der Phycomyceten. I. Zur Morphologie und Biologie der Ancylisteen und Chytridiaceen. Nova Acta K. Leop. Carol. deutsch. Akad. der Naturf., xlvii, I884, pp. 143-236, pl. I 2-2I.

\title{
EXPLANATION OF PLATES XXIII-XXVI.
}

\author{
Illustrating Mr. Barrett's paper on Olpidiopsis.
}

All figures were drawn with the aid of a camera lucida. The following combinations of objectives and oculars were used: Zeiss, apo. obj. I.5 mm. N.A. I.30, compen. oc. I8, Figs. $3^{\mathrm{I}-5}$ and $48-73$; same obj., compen. oc. 12 , Figs. 23 and $37-9$; same obj., compen. oc. 8, Figs. 1 2-I 4, 22, 4I, and 47; Zeiss apo. obj. $2 \mathrm{~mm}$. N.A. I•40, compen. oc. I2, Figs. I-4, 8-10, I5, and 40 ; Zeiss. apo. obj. $2 \mathrm{~mm}$. N.A. I.40, compen. oc. 8, Figs. 28-30, 36, and 42-6; Zeiss apo. obj. $3 \mathrm{~mm}$. dry, compen. oc. I2, Figs. I I, I $7,18,24$, and $25 ; 2 / 3$ in. obj. and I/2 in. oc., Fig. 26 ; $\mathrm{I} / 8$ in. obj. and $\mathrm{I}$ in. oc., Fig. 27.

\section{PLATE XXIII.}

Fig. I. Zoospores of Olpidiopsis luxurians. a, Drawn from a living zoospore. All others from stained preparations.

Fig. 2. Zoospores of Olpidiopsis Saprolegniae. a, From a living zoospore. All others from a stained preparation.

Fig. 3. Zoospore resting on an Aphanomyces hypha preparatory to entrance.

Fig. 4. Contents of the zoospore in the hypha, the empty spore wall outside.

Fig. 5. Germinated zoospore of $O$. luxurians on an empty sporangium of Aphanomyces laevis. laevis.

lig. 6. Germinated zoospore of $O$. luxurians on an old, but still living, hypha of Aphanomyces

Fig. 7. A young developing sporangium of $O$. luxurians five hours after infection.

$F:$. 8. Zoospore of $O$. Saprolegniae beginning to discharge its contents into the hypha of Sapróegnia ferax.

Fig. 9. Same zoospore as in Fig. 8, process nearly completed.

Fig. IO. Germinated zoospore of Aphanomyces laevis infected by 0 . luxurians.

Fig. II. Young developing sporangium of $O$. luxurians.

Fig. 12, A sporangium of $O$. luxurians, showing the homogeneous ground substance containing small granules and a few fat globules.

Fig. 13. Same sporangium as in Fig. I2, three hours later.

Fig. I4. Same as Fig. 1 2, twenty-four hours later. Zoospores formed and exit tube beginning to develop.

Fig. I5. Zoospores of $O$. vexans from a stained preparation.

Fig. I6. Intercalarily formed sporangium of $O$. luxurians showing two characteristic exit tubes.

Fig. I 7. Sporangium of $O$. luxurians, showing the recently developed membrane, vacuolate nature of the protoplasm, and the radiate character of the host protoplasm. 
Fig. I8. Stage of developing sporangium showing the organization of regular vacuoles with diminished condition of the host protoplasm.

Fig. 19. Swollen hypha of Saprolegnia containing discharged and undischarged sporangia of 0 . vexans. The latter are in the resting condition.

Fig. 20. A sporangium of $O$. vexans in an old culture, showing a peculiar coiling of the long exit tubes.

Fig. 21. A slightly swollen hypha of Saprolegnia containing three empty sporangia and two mature oospores of $O$. vexans.

Fig. 2 I A. An oospore of $O$. Saprolegniae drawn to the same scale as Fig. 2 I.

Fig. 2 I B. An oospore of $O$. luxurians drawn to the same scale as Figs. 21 and 21 A.

Fig. 22. Portion of a sporangium of $O$. luxurians stained with Gram's stain. Shows the presence of faintly stainable bodies in the vacuoles.

Fig. 23. Large fat granule from a young sporangium. Much vacuolated.

\section{PLATE XXIV.}

Fig. 24. Young oogonium and attached antheridium of $O$. luxurians.

Fig. 25. An older stage of the sexual organs of $O$.luxurians. Two young sporangia are present in the same hyphal swelling.

Fig. 26. Young developing oogonium and two antheridia of $O$. vexans. wall.

Fig. 27. Nearly mature oospore of $O$. vexans showing large oil globules and slightly roughened

Fig. 28. Young oogonium and antheridium of $O$. luxurians slightly older than Fig. 25, which shows the developing spines and the large number of oil globules, also the granular protoplasm.

Fig. 29. Same specimen as in Fig. 28, two hours later. Spines are mature and the antheridial contents is passing into the oogonium.

Fig. 30. Mature oospore of $O$. luxurians bearing two empty antheridial cells.

Fig. 3 I. Young uninucleated sporangium of $O$. vexans soon after the entrance of the zoospore into the host.

Fig. 32. Binucleated sporanginm of 0 . vexans.

Fig. 33. Binucleated sporangium of $O$. vexans, showing the nuclei in the act of division.

Fig. 34. Slightly older sporangium of $O$. vexans, showing its vacuolate character and the nuclei in division. vacuoles.

Fig. 35. Mature zoospores at the time of discharge from the sporangium, showing well-marked

Fig. 36. Sporangium of $O$. vexans, showing the peripheral arrangement of the protoplasm.

Fig. 37. Portion of a developing sporangium of 0 . vexans. The large vacuoles are forming and the nuclei are undergoing the last division before zoospore formation.

Fig. 38. A portion of a sporangium of $O$. vexans in the vacuolate stage following the condition shown in Fig. 37. Spore centres formed but not sharply marked off. Chromatin of the nuclei collected at the periphery. Fixed in weak chrom-acetic acid.

Fig. 39. A portion of a sporangium of the same age as that shown in Fig. 38, fixed in weak Flemming's solution. Segmentation of the contents into zoospores clearly visible.

\section{PLATE XXV.}

Fig. 40. Young oogonium and antheridium of $O$. vexans, showing the nuclei in a state of division. Both contain large vacuoles. Nuclei more or less irregularly distributed. No membranes apparent.

Fig. 4I. Shows the wall between the oogonium and antheridium gelatinizing to form a fertilization pore. 0. vexans.

Fig. 42. A later condition of Fig. 4I. Nuclei of antheridium in division, while those of the oogonium are in the resting condition. $O$. vexans.

Fig. 43. Sex organs of $O$. luxurians showing actual passage of male nuclei into the oogonium. Nuclei of the oogonium poorly stained. Gram stain.

Fig. 44. Fertilized oospore of $O$. vexans. The nuclei, which are very small, are collected more or less in groups. Large granules, probably fatty in nature, scattered throughout the thin protoplasm.

Fig. 45. A section of a mature oospore of $O$. luxurians, showing the thick endospore, peripheral layer of protoplasm containing the nuclei, the large central granules, and an oil globule. Nuclei very indistinct. 


\section{Barrett.-Development and Sexuality of Olpidiopsis.}

Fig. 46. An earlier stage of Fig. 45. Nuclei more clearly shown, and appear as mere rings in the protoplasm.

Fig. 47. A segment of a section of a more mature oospore of 0 . vexans. Nuclei more evenly distributed throughout the contents and much larger than in earlier stages of the oospore.

Fig. 48. Nuclei of the oospores of 0 . vexans. a, Nuclei from the section shown in Fig. 47 ; $b, c$, and $h$, apparently fusing nuclei; $d, e_{2} f$, and $g$, nuclei from such a section as shown in Fig. 44. Fusion has not yet taken place.

Figs. 49 and 50. Resting nuclei from a young oogonium.

Fig. 5I. Early prophase.

Figs. 52 and 53 . Conditions resembling synapsis.

Fig. 54. Apparent segmentation into chromosomes. evident.

Figs. 55-62, and 66. Nuclei in metaphase stages. In some cases definite chromosomes are

Figs. 63-5. Spindles in the early anaphase.

Figs. $67-70,72$, and 73 . Late anaphase.

Fig. 7 I. Telophase.

\section{PLATE XXVI.}

Fig. 74. An aphid bearing Aphanomyces infected with 0 . luxurians.

Fig. 75. An ant pupa on which is growing Saprolegnia ferax infected with 0 . vexans.

Fig. 76. A very young stage of a sporangium of $O$. luxurians.

Fig. 77. A young sporangium of 0 . luxurians, showing the large refractive fatty granules.

Figs. 78-8I. Successive stages in the development of 0 . luxurians sporangia.

Fig. 82. Sporangia showing large vacuoles and developing exit tubes.

Fig. 83. Early sexual stage of 0 . luxurians.

Figs. 84 and 85 . Later stages of sexual organs, showing large granules and vacuoles. Fig. 85 shows three antheridia attached to one oogonium.

Fig. 86. Sexual cells of $O$. luxurians about ready for fertilization to take place.

Fig. 87. Contents of antheridium partially passed into the oogonium. O. luxurians.

Fig. 88. Two oospores connected by one empty antheridium.

Fig. 89. Section of a mature oospore of 0 . luxurians stained with iron-alum haematoxylin.

Fig. 90. Similar section stained with the triple stain. 
Annals of Botany,

Vol. XXVI, Pl. XXIII.

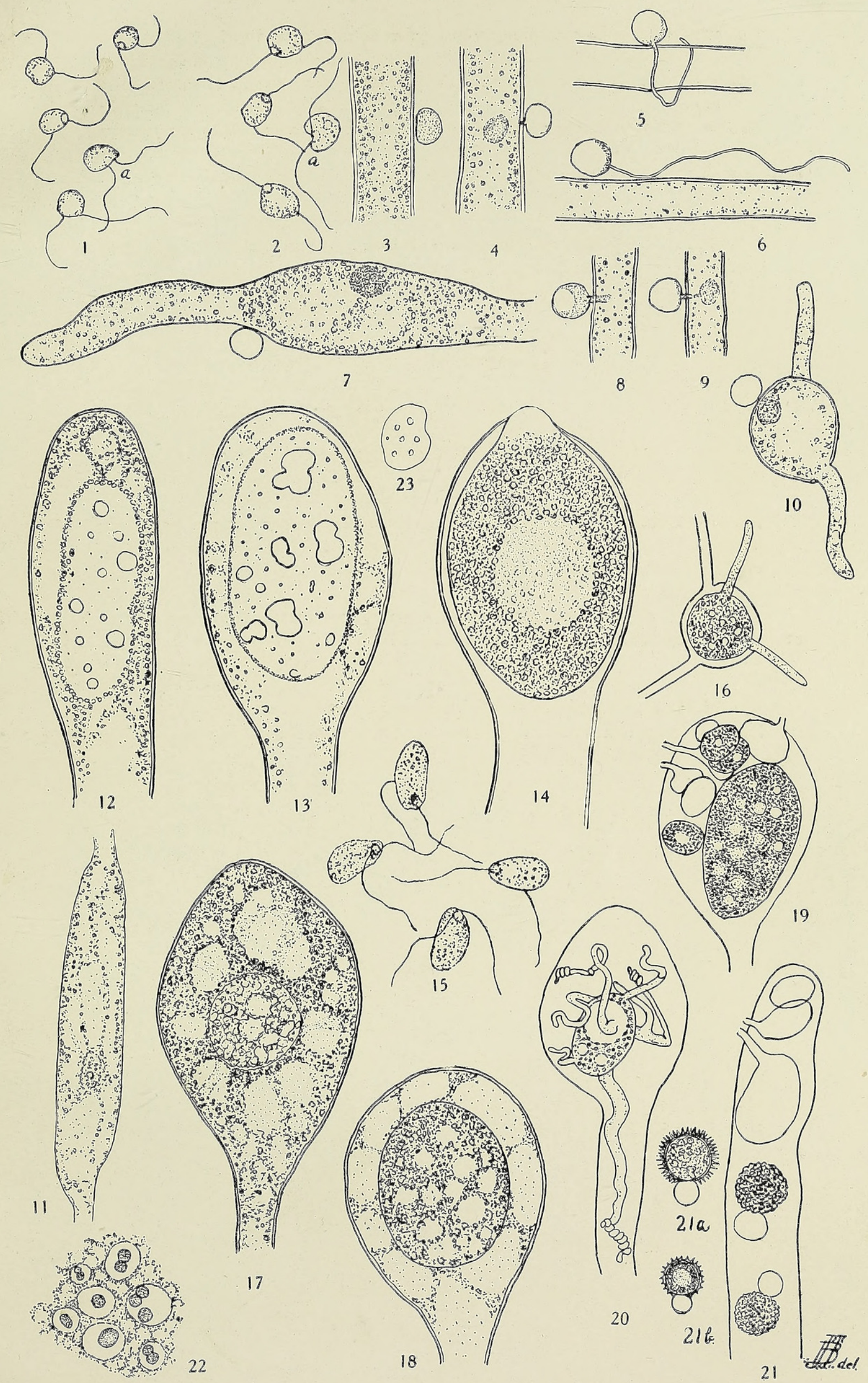




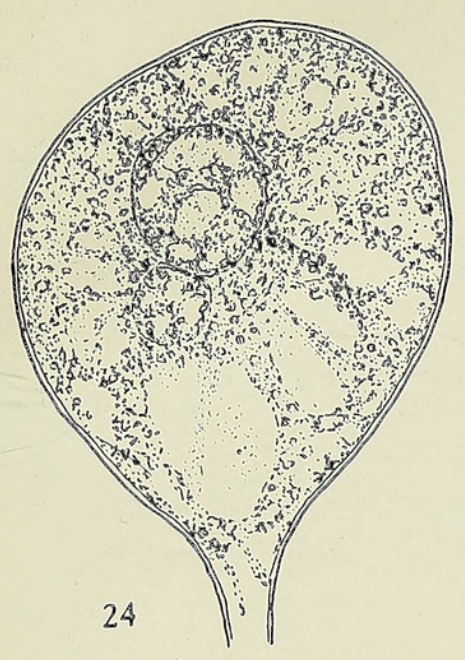

of now

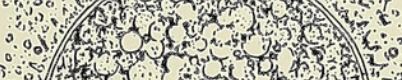

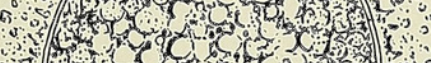

H $320 \mathrm{ccc}$, 6 . Hoces
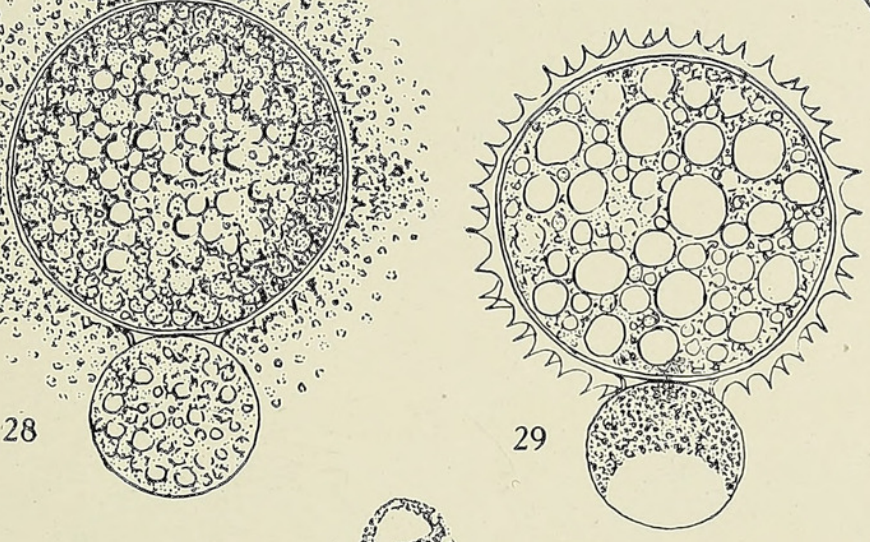

25
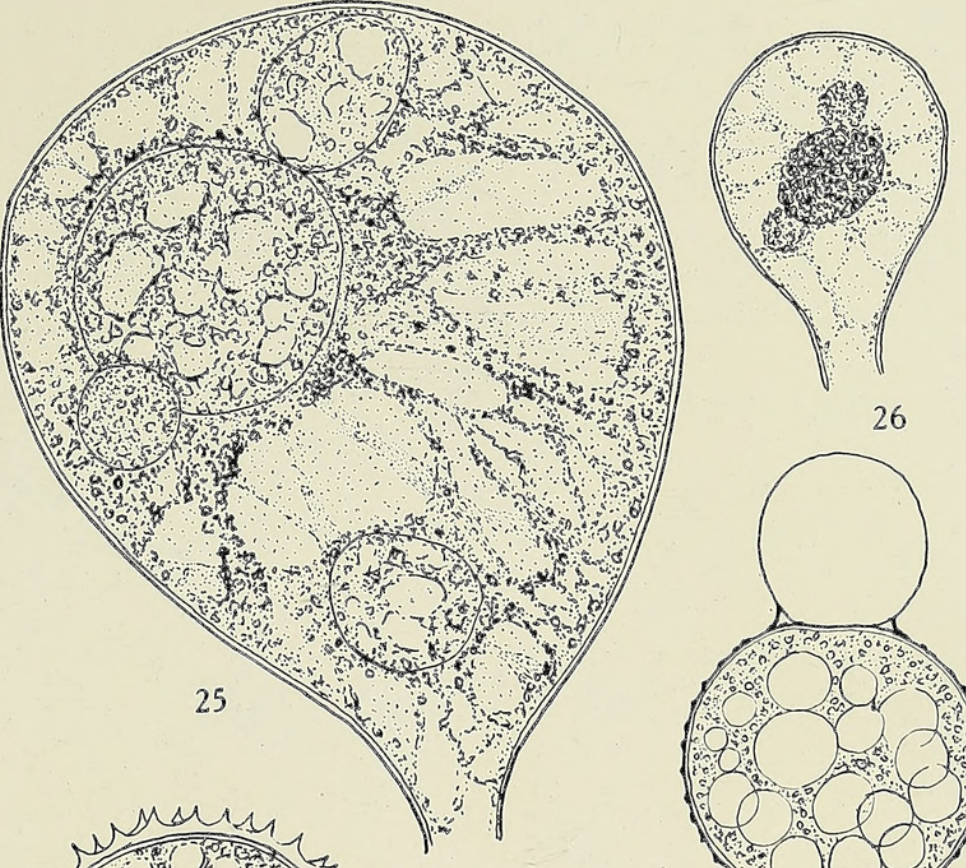

26
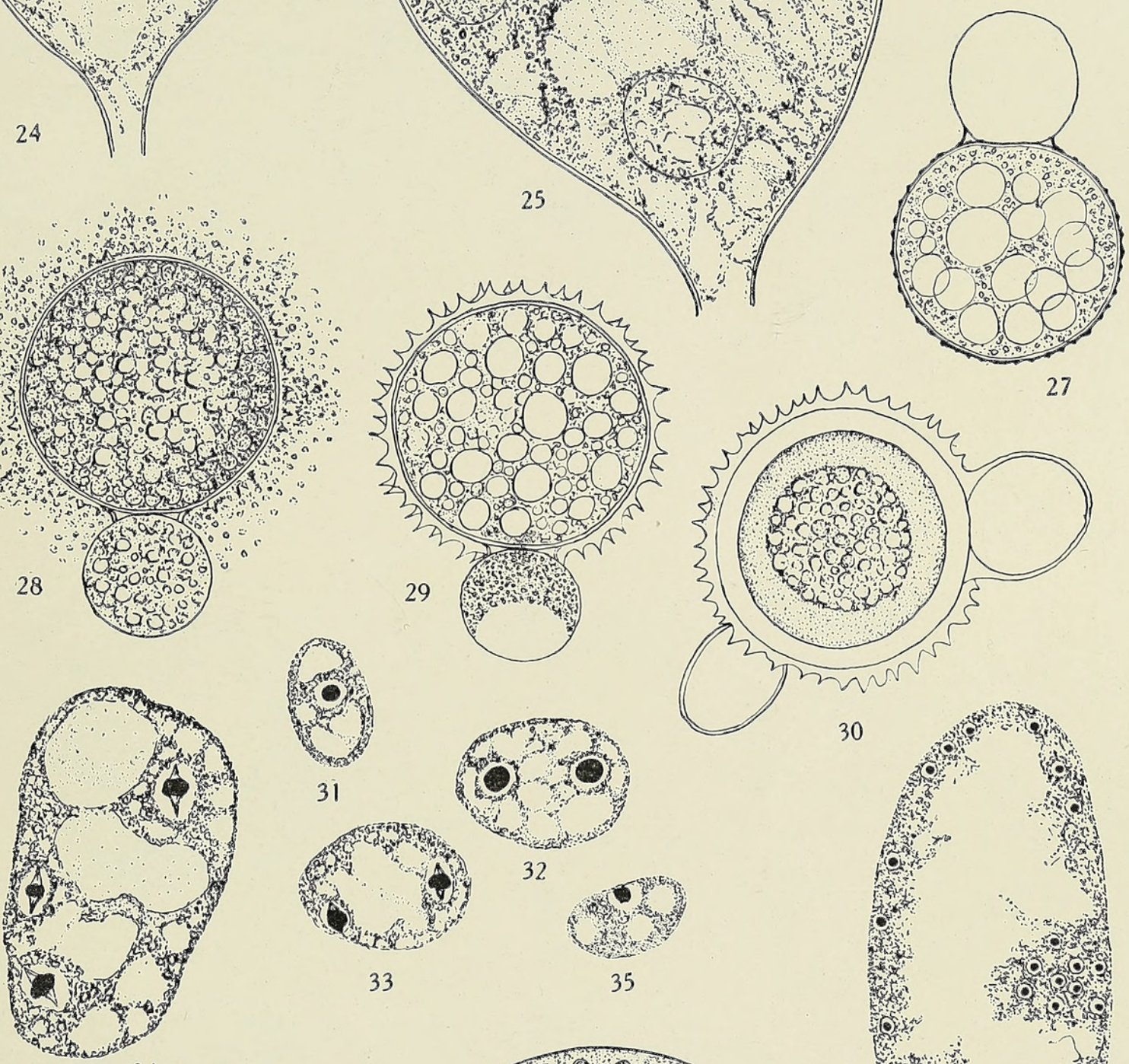

33

35
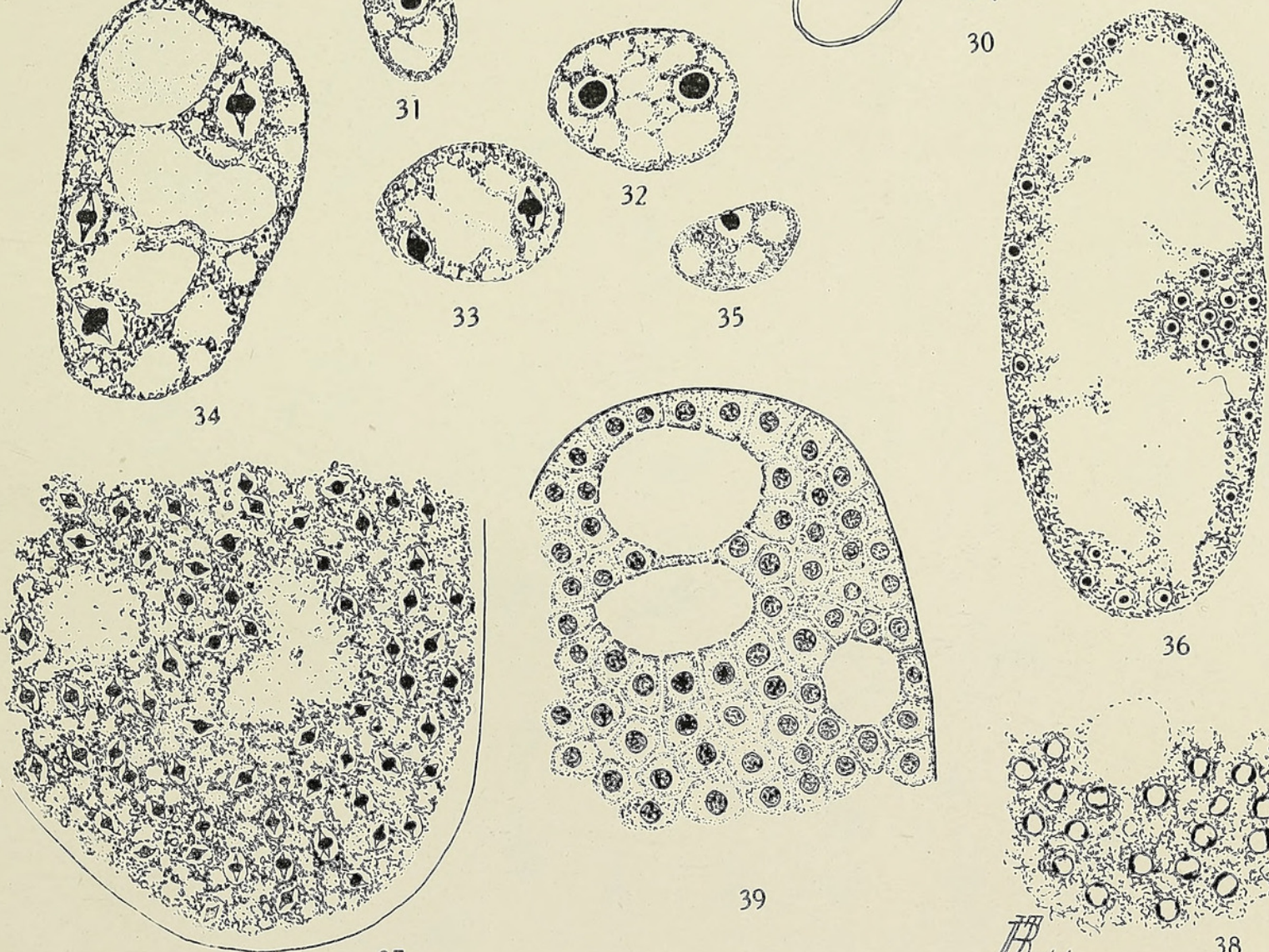

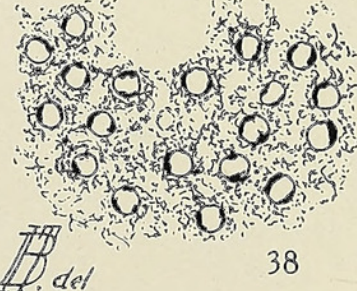




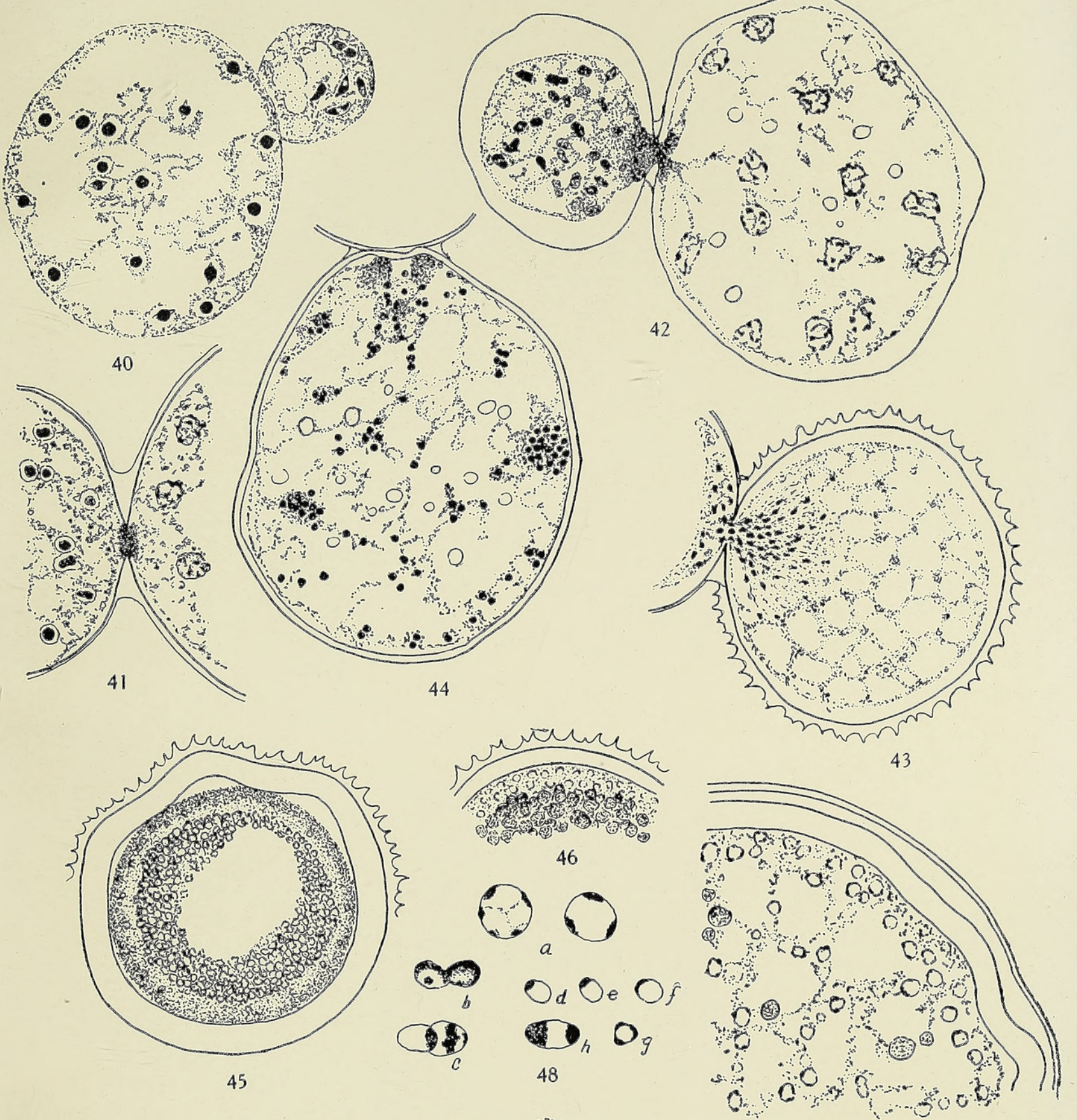

$\left.{ }_{4}\right)^{2} \mathrm{C}$
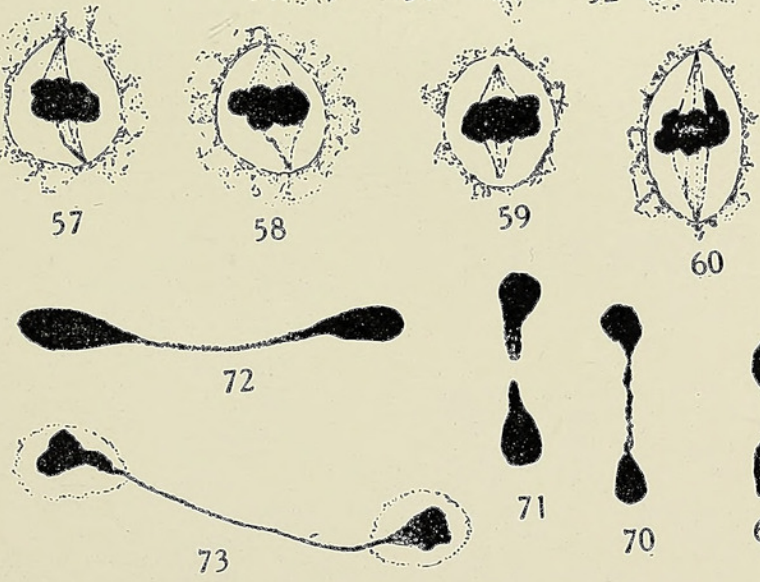
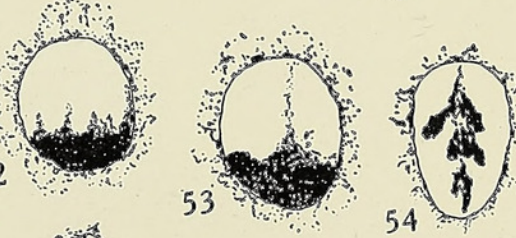

47
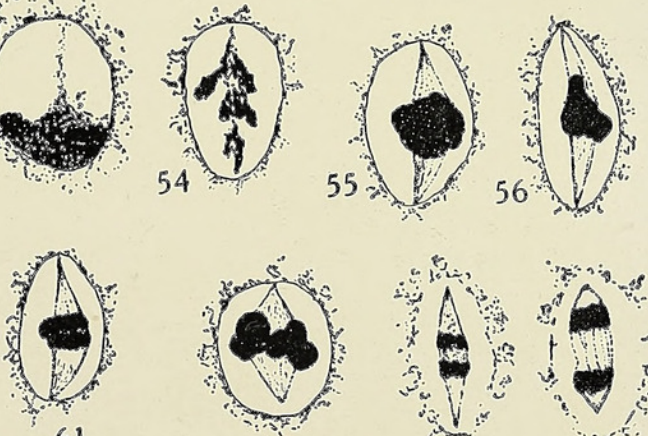

(1)

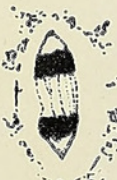

62

$63 \times 64$
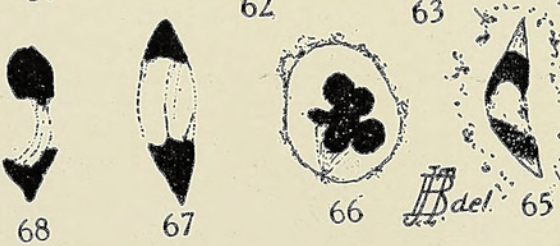
Annals of Botany

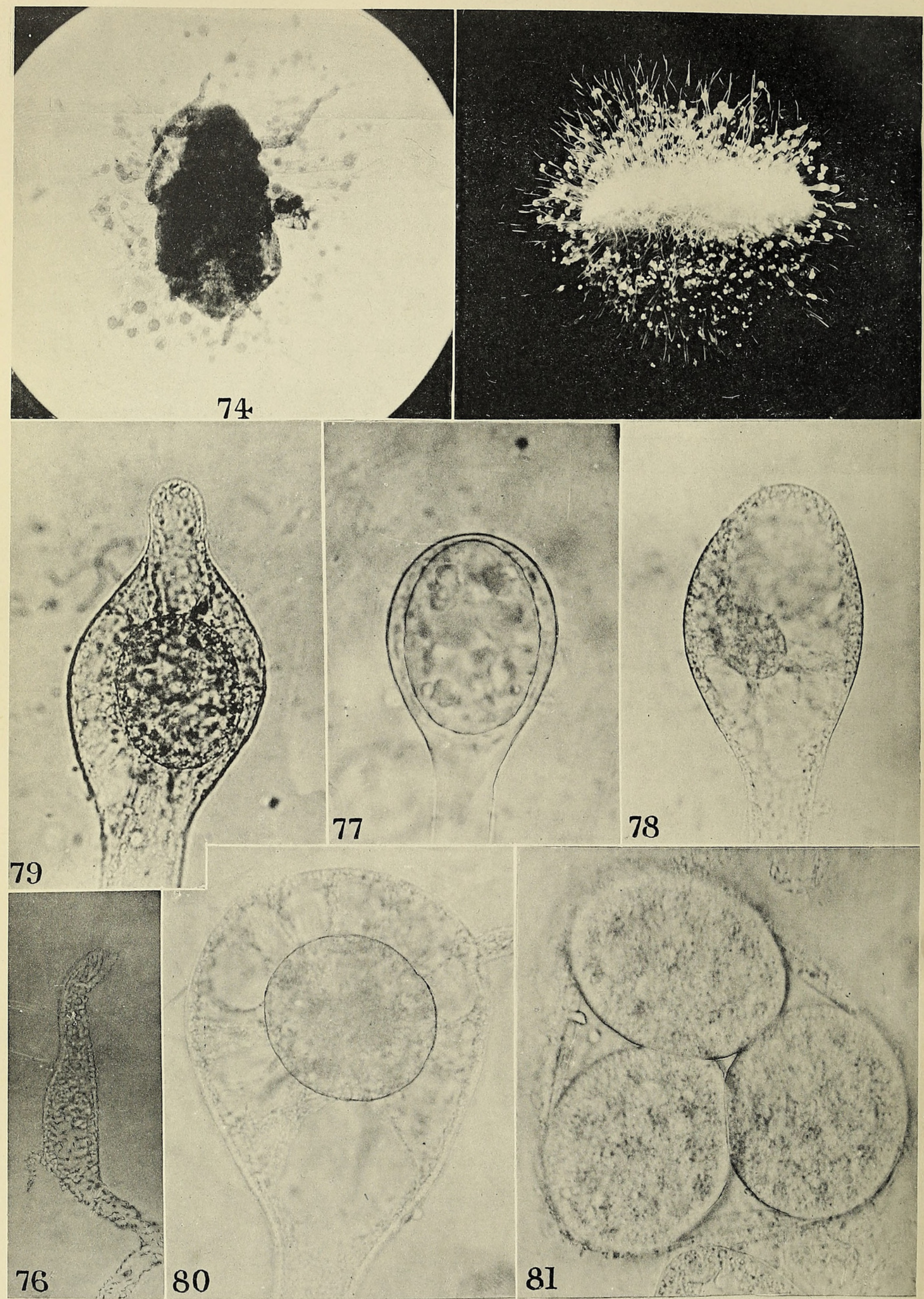

BARRETT - OLPIDIOPSIS. 
Vol.XXVI. Pl.XXVI

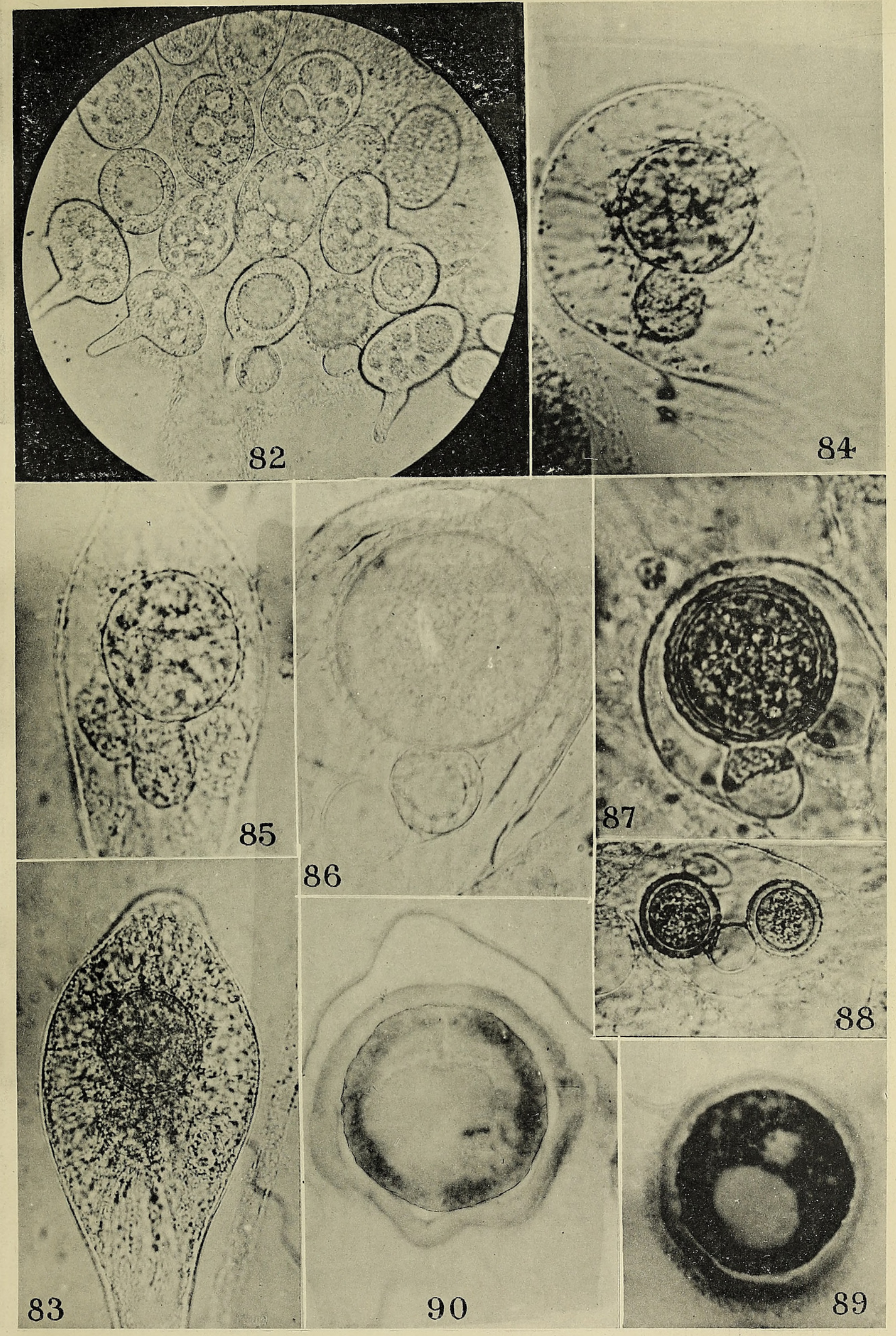




\section{$2 \mathrm{BHL}$ Biodiversity Heritage Library}

Barrett, J. T. 1912. "Development and sexuality of some species of Olpidiopsis, (Cornu) Fischer." Annals of botany 26, 209-238.

https://doi.org/10.1093/oxfordjournals.aob.a089386.

View This Item Online: https://www.biodiversitylibrary.org/item/236773

DOI: https://doi.org/10.1093/oxfordjournals.aob.a089386

Permalink: https://www.biodiversitylibrary.org/partpdf/319903

\section{Holding Institution}

Smithsonian Libraries

\section{Sponsored by}

Biodiversity Heritage Library

\section{Copyright \& Reuse}

Copyright Status: Not in copyright. The BHL knows of no copyright restrictions on this item.

This document was created from content at the Biodiversity Heritage Library, the world's largest open access digital library for biodiversity literature and archives. Visit BHL at https://www.biodiversitylibrary.org. 